\title{
Article \\ Primary Mechanical Modification to Improve Performance of Miscanthus as Stand-Alone Growing Substrates
}

\author{
Van T. H. Nguyen ${ }^{1, *(\mathbb{D})}$, Thorsten Kraska ${ }^{1,2, * \mathbb{D}}$, Winona Winkler ${ }^{1}$, Sercan Aydinlik ${ }^{1}$, Brian E. Jackson ${ }^{3}$ \\ and Ralf Pude ${ }^{1}$ (D)
}

check for updates

Citation: Nguyen, V.T.H.; Kraska, T.; Winkler, W.; Aydinlik, S.; Jackson, B.E.; Pude, R. Primary Mechanical Modification to Improve Performance of Miscanthus as Stand-Alone Growing Substrates. Agronomy 2022, 12, 420 https://doi.org/10.3390/ agronomy12020420

Academic Editor: Federica Zanetti

Received: 13 January 2022

Accepted: 4 February 2022

Published: 8 February 2022

Publisher's Note: MDPI stays neutral with regard to jurisdictional claims in published maps and institutional affiliations.

Copyright: (C) 2022 by the authors. Licensee MDPI, Basel, Switzerland. This article is an open access article distributed under the terms and conditions of the Creative Commons Attribution (CC BY) license (https:// creativecommons.org/licenses/by/ $4.0 /)$
1 Institute for Crop Science and Resource Conservation, Renewable Resources, University of Bonn, Campus Klein-Altendorf 1, 53359 Rheinbach, Germany; winona.w@uni-bonn.de (W.W.); s7seaydi@uni-bonn.de (S.A.); r.pude@uni-bonn.de (R.P.)

2 Institute for Crop Science and Resource Conservation, Horticultural Science, University of Bonn, Auf dem Hügel 6, 53121 Bonn, Germany

3 Department of Horticultural Sciences, North Carolina State University, Raleigh, NC 27695, USA; brian_jackson@ncsu.edu

* Correspondence: van.nguyen@uni-bonn.de (V.T.H.N.); kraska@uni-bonn.de (T.K.)

\begin{abstract}
Selecting proper mechanical processing can improve performance of miscanthus substrates We studied the effects of mechanical processing methods on substrate morphology, hydrological properties, $\mathrm{pH}$, and nitrogen immobilization. Miscanthus $\times$ giganteus biomass was processed into field chips (FC, forage harvester), shreds (S5, mechanical fraying machine through a 5-mm screen) and chips (C15, C10, C5 and C3, hammermill with screen size of 15, 10, 5, or $3 \mathrm{~mm}$ ). Processed miscanthus materials were also tested as propagation substrates for Chinese cabbage seedlings. Results showed that particle size distribution of miscanthus substrates formed four groups in ascending order of particle size: C3 < C5 < (C10, C15, S5) < FC. The finer miscanthus substrates had higher water holding capacity following the same groupings in particle size. The hydrophobicity of processed miscanthus was low and reversible, with the increasing order of risk as C3 < C5 < C10, C15 < S5, FC. All miscanthus substrates had similar and low $\mathrm{pH}$ buffering capacity. Nitrogen immobilization was similar among miscanthus substrates. The seedlings in miscanthus substrates had similar germination rates but a lower biomass compared to those grown in peat and coir. Primary mechanical modification of miscanthus offers opportunities for different sizes of substrate materials with few changes to the physical or chemical properties tested in this work.
\end{abstract}

Keywords: growing media; substrate processing; substrate particle; particle size; particle shape; porosity; wettability; pH buffering; nitrogen immobilization; Chinese cabbage; seedling

\section{Introduction}

Soilless cultivation of horticultural crops is projected to grow rapidly due to the increased production of ornamental and consumable (food) crops in soilless growing systems [1]. To meet the increasing global demand for soilless substrates together with reduced availability and uncertainty of peat use in many countries across Europe, the substrate industry is searching for new alternative raw materials [1]. Any suitable substrate should fulfill three requirements including reliable and consistent performance, affordability, and minimal environmental impacts [2-4].

Miscanthus (Miscanthus $\times$ giganteus), a perennial rhizomatous $\mathrm{C} 4$ grass, could be a promising renewable primary feedstock for growing substrates because of its high biomass production with low environmental impacts (low-input crop, 10-25 $t$ dry matter ha ${ }^{-1}$ annually and carbon sequestration) [5-7]. Besides its main role as a biomass crop for biofuel, miscanthus has been investigated as a soilless substrate in Europe and North America since the late 1990s. Results showed that fresh miscanthus straw could be used as substrate constituent in container substrates $(20-80 \%, v / v)$ for nursery shrubs [8-13], tomatoes [14], wood 
cuttings [15], strawberries [16,17] and as a stand-alone substrate, i.e., a sole constituent in growbags for tomatoes and cucumbers $[18,19]$. While stand-alone miscanthus in growbags showed comparable plant yield to control substrate (stone wool) [18,19], increasing the proportion of miscanthus in container substrates leads to decreasing plant growth $[9,11,12]$. Composted miscanthus could be used as a peat alternative for nursery shrubs, but the performance of tested composts in different plant trials was inconsistent [20-22]. Reported challenges of miscanthus substrate include low water holding capacity [9,11], slightly higher $\mathrm{pH}$ than the recommended range for soilless crops $[8,9,12,14,23]$, and the risk of nitrogen (N) immobilization $[11,12,14,16,23]$, thus increased substrate shrinkage for longterm cultivation $[9,21]$. Appropriate modification strategies to overcome these challenges could determine the adoption of miscanthus in the growing substrate market.

Previously studied modification strategies have focused on blending miscanthus with other substrate components rather than on exploring modifications on sole miscanthus biomass as a substrate. The blending approach has two goals: reducing the proportion of peat or other key substrate constituents in the substrates and remedying the performance limitations of tested materials [4]. While this approach is highly effective to develop substrates with direct practical importance for horticultural production, it limits insight into the performance of a single feedstock. Effects of single substrate constituents on the performance of a substrates might not be easily distinguished, particularly when our understanding of a new material is limited. In order to study the performance of miscanthus substrate, we use the "stand-alone substrate" approach. By using sole substrate component and focusing on feasible modifications on the material itself, we aim to develop a profile on the sole use of miscanthus as a substrate, which is useful both in developing further modifications and in formulating 100\% miscanthus substrates in the future, if needed.

Mechanical processing of organic biomass materials is a primary modification applied to substrate components / feedstock in order to gain desired physical properties. Substrate morphology plays an important role in determining substrate physical and hydrological properties. Studies on other organic substrates (peat, coir, bark and wood fiber) showed that finer substrate particles, i.e., particles smaller than $0.5 \mathrm{~mm}$, generally increase water holding capacity and decrease air-filled porosity in formulated substrates [24-30]. Modifying substrate morphology might also alter substrate $\mathrm{pH}$ and $\mathrm{N}$ immobilization to a certain extent. For example, fine switchgrass (Panicum virgatum) particles (hammermilled with $0.47 \mathrm{~cm}$ screen) had higher $\mathrm{pH}$ than coarse switchgrass (hammermilled with 1.25 to $2.5 \mathrm{~cm}$ screens) [31]. Fine pine tree substrates (100\% hammermilled through a $2.38 \mathrm{~mm}$ screen) have been shown to grow plants better than coarse pine tree substrate (hammermilled through a $4.76 \mathrm{~mm}$ screen) due to the higher water holding capacity [32]. The blockular shape of pine wood chips as aggregates reduced particle surface area, which might reduce the presence of microorganisms, thus less $\mathrm{N}$ immobilization [33].

As a primary material, harvested miscanthus straw can be mechanically processed by a variety of machinery types including shredders, extruders, disc refiners, and hammermills, resulting in different substrate morphology like fibers, chips, and shreds with various particle size distribution $[9,11,12,18,23]$. Shredded, extruded, and hammermilled miscanthus substrates showed different patterns of particle size distribution $[8,9,18]$; however, no hydrological properties of those sole substrates was investigated.

Miscanthus substrate has been reported to have a high $\mathrm{pH}$ in the range of 6.0-7.9 depending on the sources $[17,19,23]$. Processing miscanthus straw with extruders, retruders, or disc refiners did not affect substrate $\mathrm{pH}$, whereas steam explosion reduced substrate $\mathrm{pH}$ (from 6.7 to 4.0) [23]. The pH buffering capacity of miscanthus was thought to be low as mixing miscanthus with a small portion of peat $(20 \%, v / v)$ [9] or acid solutions [23] could bring down substrate $\mathrm{pH}$. Contrarily, it has been observed that the $\mathrm{pH}$ in the root-zone solution of tomatoes grown in miscanthus growbags was maintained around 7.0 when the $\mathrm{pH}$ of input fertilization was reduced to 4.5-except the shredded miscanthus decreased gradually, its $\mathrm{pH}$ 0.5-1.0 unit over the course of cultivation compared to hammermilled 
miscanthus [19]. To our knowledge, no empirical data on the $\mathrm{pH}$ buffering capacity of sole miscanthus substrate is available.

As a carbon $(\mathrm{C})$ rich material, miscanthus substrate poses a high risk for $\mathrm{N}$ immobilization. Increasing the proportion of miscanthus in soilless substrates has often reduced plant biomass $[9,11,12]$. Miscanthus substrates release a certain amount of water-soluble small-size $\mathrm{C}$ compounds which are available to microbes in substrate [23]. Those microbes assimilate $\mathrm{N}$ in root-zone solution causing $\mathrm{N}$ immobilization [17]. In soilless cultivation, shrubs grown in extruded miscanthus produced less biomass than those in shredded substrate [11], whereas tomatoes and cucumbers grown on extruded, shredded, and hammermilled miscanthus in growbags showed similar yield to stone wool [18]. This implies that different substrate morphology and/or cultivation techniques may create favorable or less favorable conditions for microorganism growth.

Mechanical processing could be an economical primary modification to engineer raw miscanthus biomass. Increasing the proportion of fine particles should increase water retention of the substrate; however, it might also increase substrate $\mathrm{pH}$ if miscanthus substrates perform like switchgrass substrates [31] and increase the amount of water-soluble $\mathrm{C}$ which microorganisms could easily access [23]. Additionally, grinding the miscanthus to finer substrate particle size will require more energy, thus increase production costs. Selecting a proper mechanical process to engineer a sole substrate for its best performance could be a good start for further development of miscanthus as a feedstock material. In this study, our main focus was a better understanding of miscanthus performance as a stand-alone substrate, focusing on the effect of substrate morphology after mechanical processing as a foundation for further modification and development.

Within this context, we sought to investigate how different mechanical processing methods influence miscanthus substrate morphology, hydrological properties, $\mathrm{pH}$, and $\mathrm{N}$ immobilization.

\section{Materials and Methods}

Different miscanthus substrates were produced by using a forage harvester, a mechanical fraying facility, and a hammermill with different screen sizes. Then, substrate particle size and shape distribution, hydrological properties (porosity and wettability), $\mathrm{pH}$ buffering capacity, and $\mathrm{N}$ immobilization without the presence of plants were analyzed. Finally, seedling growth of Chinese cabbage in substrates was investigated to quickly assess substrate performance under short-term cultivation conditions.

\subsection{Substrate Preparation and General Substrate Properties}

Miscanthus (Miscanthus $\times$ giganteus) cultivated at Campus Klein-Altendorf (University of Bonn, Rheinbach, Germany) was harvested at ground level using a forage harvester (Champion C1200, Kemper, Germany) in early April 2019 after winter senescence and right before new sprout emergence. The chopped material, referred to as field-chips (FC), was stored in a protected barn until it was later further processed either with a mechanical fraying facility (Type ZF 140/B4, Eirich, Germany) with screen size of $5 \mathrm{~mm}$ to produce shredded substrate (S5) or with a hammer mill (Type BHS100, Buschhoff, Germany) using different screen sizes (Table 1) to produce chips (C15, C10, C5, and C3). No further modification of the miscanthus materials was made. Two commercial substrates used in this study included unfertilized white peat amended with 30\% clay, limed to $\mathrm{pH}$ 5.5-6.5 (Null-Erde, Einheitserdewerke Werkverband e.V., Germany) and unfertilized coir (RHP Legro Kokos Erdbeeren, Legro, The Netherlands) (Table 1). The visual appearance of tested growing substrates is in the (Supplementary Figure S1). 
Table 1. List of tested growing substrates.

\begin{tabular}{ccc}
\hline Substrate & Source & Processing Method \\
\hline Peat & Unfertilized peat ${ }^{2}$ & na $^{2}$ \\
Coir & Unfertilized coir & Hammermill, screen $3 \mathrm{~mm}$ \\
C3 & Miscanthus $\times$ giganteus & Hammermill, screen $5 \mathrm{~mm}$ \\
C5 & Hammermill, screen $10 \mathrm{~mm}$ \\
C10 & Hammermill, screen $15 \mathrm{~mm}$ \\
C15 & Mechanical fraying facility, screen $5 \mathrm{~mm}$ \\
S5 & Forage harvester \\
\hline FC &
\end{tabular}

Bulk density was measured by filling fresh substrate into a cylinder $(14.7 \mathrm{~cm} \mathrm{~h} \times 14.1 \mathrm{~cm}$ i.d.) with a collar on top. The cylinder was gently dropped six times from the height of approximately $5 \mathrm{~cm}$ above a working table. After removing the collar, the substrate was levelled and weighed. The substrate was then oven-dried at $60^{\circ} \mathrm{C}$ for 3 days to determine dry weight. Bulk density was calculated as dry weight per volume $\left(\mathrm{g} \mathrm{cm}^{-3}\right)$ [34]. The $\mathrm{pH}$ [35], electrical conductivity (EC) [36], and water-soluble nutrients [37] of all substrate treatments were measured in a water-extract solution (substrate:water $=1: 5, v / v$ ). An amount of each substrate equivalent to $50 \mathrm{~mL}$ was added with $250 \mathrm{~mL}$ of demineralized water. The substrate suspension was stirred with a glass stick and then set aside at room temperature for $1 \mathrm{~h}$. Samples were stirred again before being filtered through a filter paper (MN616, Macherey-Nagel, Düren, Germany) to get filtered solution. The $\mathrm{pH}$ and EC values were determined using a $\mathrm{pH}$ meter ( $\mathrm{pH} 3000$, STEP Systems GmbH, Nürnberg, Germany) and an EC meter (FSEC20, MMM Tech Support GmbH \& Co. KG, Berlin, Germany), respectively. Nitrate $\left(\mathrm{NO}_{3}\right)$, ammonium $\left(\mathrm{NH}_{4}\right)$, and potassium $(\mathrm{K})$ ions were measured with an ion selective electrode (MULTI ISE, Stelzner, Bad Klosterlausnitz, Germany). Phosphorus (P) was measured with a portable VIS spectrophotometer (DR 1900, Hach Lange GmbH, Germany). Calcium (Ca) was measured with a Ca meter (LAQUAtwin, Horiba Scientific, Kyoto, Japan).

\subsection{Substrate Particle Size and Shape Distribution}

The profile of substrate particle size and shape was investigated with dynamic image analysis using Particle Analyzer Camsizer ${ }^{\circledR}$ P4 (Microtrac Retsch GmbH, Haan, Germany) with a size class of $0.5 \mathrm{~mm}$. Substrates were oven-dried at $60{ }^{\circ} \mathrm{C}$ for 3 days. Mild stickiness of fine particles after oven-dry was observed in peat and coir, not in miscanthus substrates. Fresh materials of peat and coir were sieved before oven-dry to separate fine and coarse particles as a preventative measure. Dried substrates were gently mashed through a screen in case of stickiness. Oven-dried substrates were divided into sub-samples (approximately $25 \mathrm{~g}$ dry weight, 4 replicates) with the rotating sample divider (Microtrac Retsch $\mathrm{GmbH}$, Haan, Germany). Substrate particles were added to a dosage funnel, then transported along a vibrating feeder until they fell freely into a measurement shaft where two highspeed cameras (basic and zoom cameras for large particles $300 \mu \mathrm{m}-30 \mathrm{~mm}$ and small particles $30 \mu \mathrm{m}-3 \mathrm{~mm}$, respectively) would capture their images. The images would then be processed with the integrated Camsizer ${ }^{\circledR} \mathrm{P} 4$ software (version 6.6.5.1060) to characterize the volume-based distribution of size and shape of particle projection (Table 2) [38].

Two main size parameters are particle width $\left(x_{c \min }\right)$ as the shortest chord diameter and particle length $\left(x_{\text {Femax }}\right)$ as the longest Feret diameter, which were determined out of the measured set of maximum chord diameter and maximum Feret diameter of particle projection, respectively (Table 2, Figure 1). The chord diameter is the longest distance between two horizontal points of the particle contour. The Feret diameter is the distance between two parallel tangents which are perpendicular to the measuring direction. The ellipsoid model was used to calculate particle volume as $\mathrm{V}=\frac{\pi}{6} \cdot x_{\text {Femax }} \cdot x_{c \min }^{2}$. In this study, 
particle size distribution of substrates was described as cumulative particle size distribution, its percentile values $(\mathrm{d} 10, \mathrm{~d} 50, \mathrm{~d} 90)$ and non-uniformity indicator $\left(\mathrm{U} 3\right.$, as $\left.\frac{d 60}{d 10}\right)$. Fractions of particle size were categorized into fine $(<0.5 \mathrm{~mm})$, medium $(0.5-2.0 \mathrm{~mm})$, and coarse particles $(>2.0 \mathrm{~mm})$ [39]. The specific surface parameter $(\mathrm{Sv})$ was calculated over the whole sample as the ratio of surface area of all particles to total volume of all particles. These parameters were determined for particle width and particle length.

Particle shape distribution was monitored via aspect ratio (b/l), sphericity (SPHT), convexity (Conv), and symmetry (Symm) (Table 2). Values of shape parameters range between 0 and 1, with a perfect circular shape, very smooth surface or perfectly symmetrical shape having a value of 1 . The more particle shape deviates from circle/sphere, smooth surface, or symmetrical shape, the lower the value. As an indicator of particle elongation, aspect ratio $(\mathrm{b} / \mathrm{l})$ is calculated as the ratio of particle width $\left(x_{\text {cmin }}\right)$ to particle length $\left(x_{\text {Femax }}\right)$. Sphericity (SPHT) is the ratio of a particle area to the perimeter of particle projection. Convexity (Conv) is the ratio of the real area of a particle projection to its convex hull. The convex hull is calculated from an imaginary elastic band stretched around a particle contour [40]. Both sphericity and convexity indicate the surface roughness of particles [41,42]. Symmetry measures the eccentricity of particle projection by determining the centroid of particle projection, then calculating the minimum ratio of two opposing semi axes through the centroid point. Besides the cumulative particle shape distribution of the four shape parameters, the mean values of aspect ratio, sphericity, and symmetry were calculated at each size fraction (fine, medium, and coarse).

Table 2. Volumetric parameters of particle size and shape analyzed with Particle Analyzer Camsizer.

\begin{tabular}{|c|c|}
\hline $\begin{array}{l}\text { Parameter } \\
\text { (Camsizer's Parameter) }\end{array}$ & Definition [38] \\
\hline & Particle size \\
\hline Particle width $\left(x_{c m i n}\right)$ & The shortest chord diameter of the measured set of maximum chords of a particle projection. \\
\hline Particle length $\left(x_{F e m a x}\right)$ & The longest Feret diameter of the measured set of Feret diameter of a particle projection. \\
\hline Percentile values d10, d50, d90 & $\begin{array}{l}\text { The value of particle size when the proportion of particles with size smaller than that value } \\
\text { is } 10,50 \text {, and } 90 \% \text {, respectively. }\end{array}$ \\
\hline Non-uniformity (U3) & $\begin{array}{l}\mathrm{U} 3=\frac{d 60}{d 10} \\
\text { It indicates homogeneity of particle size distribution. }\end{array}$ \\
\hline Specific surface (Sv) & The ratio of surface of all particles and volume of all particles. \\
\hline & Particle shape \\
\hline Aspect ratio $(b / 1)$ & $\begin{array}{l}\qquad \mathrm{b} / 1=\frac{x_{\text {cmin }}}{x_{\text {Femax }}}(0<\mathrm{b} / 1 \leq 1) \\
\text { The ratio of particle width to particle length of a particle projection. } \\
\text { It is a measurement of particle elongation }(\mathrm{a} \text { perfect circle has } \mathrm{b} / 1 \text { value of } 1) \text {. }\end{array}$ \\
\hline Sphericity (SPHT) & $\begin{array}{c}\text { SPHT }=\frac{4 \pi A}{P^{2}}(0<\mathrm{SPHT} \leq 1) \\
(P: \text { measured perimeter of a particle projection, } \\
A \text { : measured area covered by a particle projection }) \\
\text { It is an indicator of surface roughness (an ideal sphere has SPHT value of } 1)[42,43] .\end{array}$ \\
\hline Convexity (Conv) & $\begin{array}{l}\text { Conv }=\sqrt{\frac{A_{\text {real }}}{A_{\text {convex }}}}(0<\text { Conv } \leq 1) \\
\text { The ratio of the real area }\left(A_{\text {real }}\right) \text { of a particle projection to its convex hull }\left(A_{\text {convex }}\right)(\text { an } \\
\text { imaginary elastic band stretched around the particle projection). It indicates the particle } \\
\text { edge roughness (particle with very smooth surface has Conv value of } 1) \text { [41]. }\end{array}$ \\
\hline Symmetry (Symm) & $\begin{array}{l}\qquad \text { Symm }=\frac{1}{2}\left[1+\min \left(\frac{r_{1}}{r_{2}}\right)\right](0<\text { Symm } \leq 1) \\
\text { A measure of the eccentricity of the particle image by determining the centroid of particle } \\
\text { projection, then calculating the minimum ratio of two opposing semi axes }\left(r_{1}, r_{2}\right) \text { through } \\
\text { the centroid point (a symmetrical shape has Symm value of } 1) .\end{array}$ \\
\hline
\end{tabular}



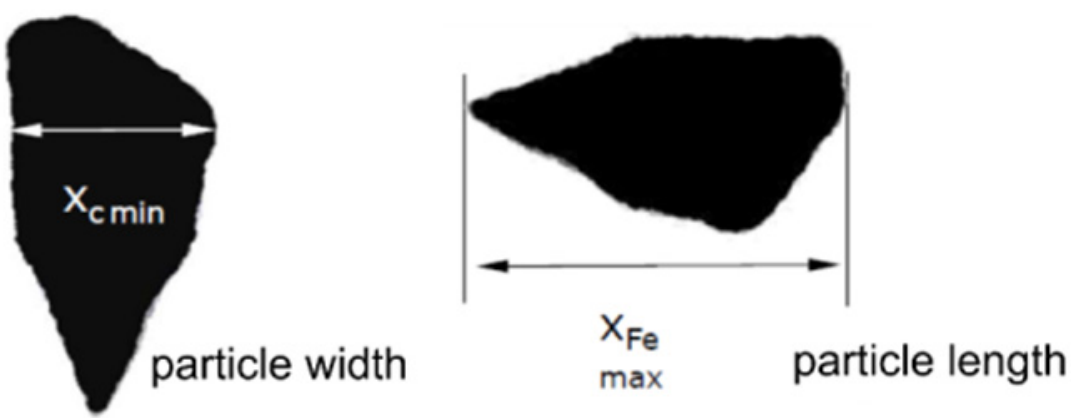

Figure 1. Two main particle size parameters analyzed with Particle Analyzer Camsizer: particle width $\left(x_{c \text { min }}\right.$, the shortest chord diameter), particle length $\left(x_{\text {Femax }}\right.$, the longest Feret diameter) (adapted from [44].).

\subsection{Substrate Hydrological Properties: Porosity and Wettability}

The hydrological properties of substrates were characterized by porosity and wettability measurements. Substrate porosity, i.e., total pore volume of a substrate and its proportion for air and water, was determined by using a modified North Carolina State University Porometer [45]. Substrate wettability describes how easily the substrate can be wetted. To assess substrate wettability, we used the hydration efficiency test developed by Fonteno et al., 2013 [46,47].

Substrate porosity: Substrates were prewetted to their target wet mass values, then left overnight to avoid stickiness of fine particles (Supplementary Table S1). The target wet mass values were chosen based on a preliminary test. At target wet mass, substrate particles were wetted to allow their swelling so that substrates would not swell in the porometer. A transparent acrylic column beaker served as the modified porometer $(9 \mathrm{~cm} \mathrm{~h} \times 6.7 \mathrm{~cm}$ i.d., $\left.\mathrm{V}=317.1 \mathrm{~cm}^{3}\right)$. The beaker had 5 drainage holes $(5 \mathrm{~mm}$ diameter $)$ at the bottom. Moist substrates were filled into the beaker (with a collar on top) using a step-wise procedure (8 replicates). The surface of the substrate was levelled. The beakers were then placed into a level container. Water was slowly added to the container using a step-wise procedure until the water level reached almost the rim of the beaker. Substrates were allowed to saturate for 30 mins. An air-tight plastic plate and a weight were placed on the beaker to create an air-tight condition to prevent water leakage. The beaker was then gently lifted out of the container and placed in an empty cup to collect drainage water. After 30 mins, the drainage volume was recorded. The fresh weight of wet substrate was recorded. Substrates were then oven dried at $60^{\circ} \mathrm{C}$ for 3 days for dry weight measurements. The air-filled porosity (pore volume of substrate which air occupies), water holding capacity (pore volume of substrate which water occupies), and porosity were calculated as below.

Water holding capacity: $\mathrm{WHC}(\%)=100 *\left(\mathrm{~m}_{\text {substrate after drain }}-\mathrm{m}_{\text {substrate after dry }}\right) / \mathrm{V}_{\text {beaker }}$ Air-filled porosity: $\quad \operatorname{AFP}(\%)=100 *\left(\mathrm{~V}_{\text {drainage }} / \mathrm{V}_{\text {beaker }}\right)$

Porosity:$$
\mathrm{P}(\%)=\mathrm{WHC}+\mathrm{AFP}
$$

Substrate wettability: To assess wettability, we evaluated hydration performance of substrates at different initial moisture contents (IMC) including non-wet, IMC 67\%, IMC $50 \%$, and ICM $25 \%(w / w)$. Non-wet indicates the natural (unmodified) moisture status of miscanthus substrates and the moisture status at delivery for peat and coir, i.e., their moisture content was pre-adjusted by substrate manufacturer (Supplementary Figure S2). No additional wetting was applied to non-wet substrates. Substrates at IMC $67 \%, 50 \%$, and $25 \%$ were prepared by wetting substrates (i.e., non-wet materials) with water to $67 \%(w / w)$, then air-drying until substrates reached their target IMC. Substrates were kept in ziplock bags to maintain their target IMC. Substrates were packed into transparent acrylic cylinders $(6.5 \mathrm{~cm}$ i.d.) with screens at the bottom (mesh size of $1 \times 1 \mathrm{~mm}$ ) to get $230 \mathrm{~mL}$ of substrate. Ten successive hydration events of $230 \mathrm{~mL}$ water each were applied to the top of the substrate column with flowing rate of $50 \mathrm{~mL} \mathrm{~min}^{-1}$. Water drainage was collected 
and measured after each hydration event. Water retention in the substrate column was calculated as the difference between water applied $(230 \mathrm{~mL})$ and water drainage. After 10 events, any change in substrate heights was recorded. The water holding capacity was tested for each cylinder using the same protocol for porosity which was described previously. Hydration properties were estimated for each substrate at 4 previously described IMC's using three criteria: (1) how fast substrate columns reached their maximum water retention within 10 events, (2) how much water absorbed after the first event compared to maximum water retention within 10 events, and (3) how much maximum water retention within 10 events compared to its maximum WHC. Instead of using water-holing capacity (i.e., container capacity) as the reference value, we used maximum water retention within 10 applied events as it described better hydration properties of a substrate from the same feedstock (miscanthus) with different particle size distribution. Those criteria are defined in the below parameters.

Hydration speed (HS): number of hydration events applied until the substrate column reaches $90 \%$ of its maximum water retention within 10 applied events.

Initial hydration efficiency (HE1): the ratio of water retention in a substrate after the first event to maximum water retention within 10 events.

Retention efficiency (RE): the ratio of maximum water retention within 10 events to WHC.

Swelling (\%): the proportion of swollen volume after 10 hydration events to the initial volume height of a substrate.

\section{4. $p H$ Buffering Capacity}

The $\mathrm{pH}$ buffering capacity was measured using the procedure described for compost by Costello and Sullivan (2014) [48]. First, to determine the time when the substrate $\mathrm{pH}$ becomes stable after acid addition, an amount of fresh $\mathrm{C} 3$ and $\mathrm{S} 5$ equivalent to $5 \mathrm{~g}$ of dry weight was added to a $120-\mathrm{mL}$ beaker. A total of $50 \mathrm{~mL}$ of 3 acid concentrations $(\mathrm{HCl})$ were added into beakers resulting in 3 rates of $0,0.01$, and $0.1 \mathrm{~mol} \mathrm{H}^{+} \mathrm{kg}^{-1}$ substrate equivalent to $\mathrm{pH} 7, \mathrm{pH} 3$, and $\mathrm{pH} 2$, respectively. The beakers were closed with a cap to avoid atmospheric carbon dioxide penetration. The substrate $\mathrm{pH}$ in the suspension was measured at $0.4,1,2,3,4,5,6,7,24$, and $48 \mathrm{~h}$ after acid was added. The time point at $24 \mathrm{~h}$ after acid addition was selected to determine $\mathrm{pH}$ buffering capacity (Supplementary Figure S3). An amount of fresh substrate equivalent to $5 \mathrm{~g}$ of dry weight was added with $50 \mathrm{~mL}$ of 5 acid concentrations as $0,0.01,0.05,0.1$ and $0.3 \mathrm{~mol} \mathrm{H}^{+} \mathrm{kg}^{-1}$ substrate equivalent to $\mathrm{pH}$ of 7.0, $3.0,2.3,2.0$ and 1.5, respectively (5 replicates). The substrate $\mathrm{pH}$ was measured at $24 \mathrm{~h}$ after acid addition. Linear regression was plotted between proton concentration and substrate $\mathrm{pH}$. The $\mathrm{pH}$ buffering capacity is the amount of proton needed to reduce substrate $\mathrm{pH}$ by one unit, and it is calculated as below.

$\mathrm{pH}$ buffering capacity $=(1 /$ slope $)$

slope is the fitted slope of linear regression for each substrate

\subsection{N Immobilization}

The $\mathrm{N}$ immobilization rate was tested based on the $\mathrm{N}$ drawdown index (NDI) described by Handreck (1992) [49]. Substrates were incubated at N rates of 0 and $300 \mathrm{mg} \mathrm{N} \mathrm{L}^{-1}$ using $\mathrm{KNO}_{3}$ fertilizer (YaraTera ${ }^{\mathrm{TM}} \mathrm{Krista}^{\mathrm{TM}} \mathrm{K}$ Plus, Yara Deutschalnd, Dülmen, Germany) for 4 days. Preliminary experiments with rates of $\mathrm{N}$ were conducted and from those data it was determined that $300 \mathrm{mg} \mathrm{N} \mathrm{L}^{-1}$ was the best rate to assess $\mathrm{N}$ immobilization; therefore, data presented in this paper are from experiments conducted with $300 \mathrm{ppm} N$ only. Substrates were pre-moistened to $65 \%$ moisture content $(v / v)$ for 8 days prior to incubation. Substrates were then filled into commercial pots $(11 \mathrm{~cm}, \mathrm{~V}$ of $400 \mathrm{~mL})$ to the brim and placed on benches in a greenhouse. One volume of demineralized water $(400 \mathrm{~mL})$ was slowly poured through the substrate in the pot. The charging process, i.e., adding $\mathrm{KNO}_{3}$ solution to the substrate, was done by slowly pouring $400 \mathrm{~mL} \mathrm{KNO}_{3}$ solution at two $\mathrm{N}$ rates $\left(0\right.$ and $\left.300 \mathrm{mg} \mathrm{N} \mathrm{L}^{-1}\right)$ through the substrate in the pot, waiting for 30 mins, and then 
adding a second $400 \mathrm{~mL} \mathrm{KNO}_{3}$ solution. After drainage, pots weights were recorded and then covered with plastic foil with small holes to reduce evaporation. At the measurement dates, demineralized water was added to bring pot weights to their initial values at the start of incubation. The substrate solution was then extracted by adding $300 \mathrm{~mL}\left(\frac{3}{4}\right.$ volume of substrate volume) of demineralized water, then filtering using filter paper (MN616, Macherey-Nagel, Germany). The $\mathrm{NO}_{3}$ concentration in the extract solution was measured with an ion-selective electrode (MULTI ISE, Stelzner, Bad Klosterlausnitz, Germany) on the same day of extraction. The NDI was calculated as the ratio of $\mathrm{NO}_{3}$ concentration in the extract solution at the measurement date to the $\mathrm{NO}_{3}$ concentration in the extract solution at the start of incubation. The smaller value of NDI (smaller than 1) indicates a higher $\mathrm{N}$ immobilization.

\subsection{Substrate Performance as Growing Substrate for Chinese Cabbage Seedlings}

Chinese cabbage (Brassica rapa spp. pekinensi, 'Pacifiko F1', Bejo Samen GmbH) was used to test the performance of substrates under short-term cultivation. The substrates were moistened to about $65 \%$ moisture content $(v / v)$ right before being filled into the sowing tray (77 cells, rectangular cell $4 \mathrm{~cm} \times 4 \mathrm{~cm}, 5 \mathrm{~cm} \mathrm{~h}$ ). One seed was hand sown into each cell. The trays were placed onto greenhouse benches with subirrigation from an ebb and flow system. Since all tested substrates were unfertilized, fertigation with nutrient solution (pH 5.5, EC 2.6 dS m ${ }^{-1}$, Supplementary Table S2) was applied once per day (3-min duration) beginning on the sowing date.

The germination rate was recorded daily until day 9. Seedling emergence was counted when the cotyledons came through the surface of the substrates. Mean seed emergence time (MSET) was calculated as MSET $=\sum \mathrm{n} . \mathrm{t} / \sum \mathrm{t}$, with $\mathrm{n}$ as the number of newly emerged seedling at a time interval $t$. Spectral reflectance of the first leaf, i.e., the oldest leaf, was measured with the portable spectro-radiometer Polypen (Photon Systems Instruments, Drásov, Czech Republic) at day 23. Based on spectral reflectance, vegetation indices as indicators for chlorophyll content were computed as below [50].

$$
\begin{aligned}
& \text { Carter index }=\frac{1}{\text { Reflectance }_{550 \mathrm{~nm}}} \\
& \text { Datt index }=\frac{\text { Reflectance }_{672 \mathrm{~nm}}}{\left(\text { Reflectance }_{550 \mathrm{~nm}} \cdot \text { Reflectance }_{708 \mathrm{~nm}}\right)}
\end{aligned}
$$

Once seedlings reached their commercial transplanting size (5-leaf stage, 24 days after sowing), we measured the seedling above-ground biomass, leaf number, and total leaf area for a single seedling (72 seedlings each substrate). Seedlings were oven dried at $105{ }^{\circ} \mathrm{C}$ for 2 days to get dry biomass. The substrate $\mathrm{pH}, \mathrm{EC}$, and water-soluble nutrients $\left(\mathrm{NO}_{3}, \mathrm{NH}_{4}\right.$, $\mathrm{P}, \mathrm{K}$ and $\mathrm{Ca}$ ) were monitored in substrate cells without seedlings (day 4, 8, 12, 16, 20 and 24) and for substrate cells with seedlings (day 9 and 17). At each sampling date, substrates from three sowing cells were collected and loosely packed in a beaker. Demineralized water was then slowly added into the beaker to reach the saturation status. After one hour, the substrate suspension was stirred with a glass stick, then filtered to get the extraction solution. The experiment was designed as a randomized block design with 4 replicates, each replicate was 1 sowing tray with 45 seeds. Each block was 1 greenhouse bench on which 8 sowing trays of 8 tested substrates were placed.

\subsection{Statistical Analysis}

The mean difference of tested parameters among tested substrates was conducted using one-way ANOVA. The multiple comparisons post hoc is Tukey's HSD ( $p$-value $\leq 0.05$ ). The R software version 4.0.2 was used.

\section{Results}

\subsection{General Substrate Properties}

Miscanthus substrates had different EC values and a different bulk density, $\mathrm{pH}$, and water-soluble nutrient concentration compared to peat and coir (Table 3). The bulk densities of miscanthus substrates were lower than peat and higher than coir. The initial moisture content of miscanthus substrates at processing were lower than the packing moisture 
content of commercial peat and coir (10\% vs. 40-50\%,w/w). Miscanthus substrates had slightly acidic $\mathrm{pH}$. According to the English Agricultural Development and Advisory Service (ADAS) method [51,52], EC values of miscanthus were moderate to fairly high. Miscanthus substrates released a significant amount of $\mathrm{NO}_{3}, \mathrm{NH}_{4}, \mathrm{P}, \mathrm{K}$, and $\mathrm{Ca}$. The $\mathrm{NO}_{3}$ released from miscanthus substrates belonged to indices 1 and 2 within the range of seven indices from low to high concentration. Having an index of 2 to 3 , the $\mathrm{NH}_{4}$ concentration released from miscanthus was considered fairly high to young plants [51]. The P and K concentration also belong to high indices.

Table 3. Bulk density, moisture content, $\mathrm{pH}$, electrical conductivity (EC), and water-soluble of nutrients of peat, coir, and processed miscanthus substrates.

\begin{tabular}{|c|c|c|c|c|c|c|c|c|c|}
\hline \multirow{2}{*}{ Substrate } & \multirow{2}{*}{$\begin{array}{l}\text { Bulk Density } \\
\qquad\left(\mathrm{g} \mathrm{cm}^{-3}\right)\end{array}$} & \multirow{2}{*}{$\begin{array}{c}\text { Moisture } \\
\text { Content (\%) }\end{array}$} & \multirow{2}{*}{$\mathrm{pH}^{1}$} & \multirow{2}{*}{$E C\left(d S m^{-1}\right)^{1}$} & \multicolumn{5}{|c|}{ Water-Soluble Nutrient (mg L ${ }^{-1}$ Substrate) ${ }^{1}$} \\
\hline & & & & & $\mathrm{NO}_{3}$ & $\mathrm{NH}_{4}$ & $\mathbf{P}$ & $\mathbf{K}$ & Ca \\
\hline Peat & $0.22 \mathrm{a}$ & $40.3 \mathrm{~b}$ & $6.6 \mathrm{~b}$ & nd. & nd. & nd. & $42.7 \mathrm{~d}$ & $3.8 \mathrm{f}$ & nd. \\
\hline Coir & $0.09 \mathrm{f}$ & $51.1 \mathrm{a}$ & $6.7 \mathrm{a}$ & nd. & nd. & $6.3 \mathrm{e}$ & nd. & $28.8 \mathrm{f}$ & nd. \\
\hline C3 & $0.16 \mathrm{~b}$ & $9.7 \mathrm{~cd}$ & $6.2 \mathrm{~cd}$ & $0.7 \mathrm{a}$ & $32.5 \mathrm{a}$ & $117.5 \mathrm{a}$ & $144.3 \mathrm{a}$ & $1861.3 \mathrm{a}$ & $48.8 \mathrm{a}$ \\
\hline C5 & $0.14 \mathrm{c}$ & $10.1 \mathrm{~cd}$ & $6.3 \mathrm{~cd}$ & $0.6 \mathrm{~b}$ & $25.0 \mathrm{abc}$ & $107.5 \mathrm{~b}$ & $117.6 \mathrm{~b}$ & $1678.8 \mathrm{~b}$ & $33.8 \mathrm{ab}$ \\
\hline C10 & $0.13 \mathrm{~d}$ & $10.3 \mathrm{~cd}$ & $6.3 c$ & $0.5 c$ & $23.8 \mathrm{abc}$ & $103.8 \mathrm{~b}$ & $101.7 \mathrm{~b}$ & $1551.3 \mathrm{c}$ & $23.8 \mathrm{~b}$ \\
\hline C15 & $0.12 \mathrm{~d}$ & $9.2 \mathrm{~d}$ & $6.3 \mathrm{~cd}$ & $0.4 \mathrm{~d}$ & $20.0 \mathrm{bc}$ & $90.0 \mathrm{c}$ & $67.6 \mathrm{c}$ & $1321.3 \mathrm{~d}$ & $26.3 \mathrm{~b}$ \\
\hline S5 & $0.15 c$ & $10.6 \mathrm{~cd}$ & $6.2 \mathrm{~d}$ & $0.5 c$ & $27.5 \mathrm{ab}$ & $100.0 \mathrm{~b}$ & $99.5 \mathrm{~b}$ & $1541.3 \mathrm{c}$ & $31.3 \mathrm{~b}$ \\
\hline FC & $0.10 \mathrm{e}$ & $12.3 \mathrm{c}$ & $6.3 \mathrm{~cd}$ & $0.3 \mathrm{e}$ & $16.3 \mathrm{c}$ & $80.0 \mathrm{~d}$ & $50.6 \mathrm{~cd}$ & $1041.3 \mathrm{e}$ & $21.3 \mathrm{~b}$ \\
\hline
\end{tabular}

${ }^{1} \mathrm{pH}, \mathrm{EC}$, and water-soluble nutrients were measured using the 1:5 volume method (substrate:demineralized water $=1: 5, v / v)$.; Different lower case letters indicate statistically significant differences in means among eight substrates at each substrate parameter in each column (Tukey's HSD, $p \leq 0.05, \mathrm{n}=4$ ). nd.: non-detectable concentration within the measurement range of the devices.; Miscanthus $\times$ giganteus was harvested with forage harvester (FC, field-chips), then processed with a mechanical fraying facility through a 5-mm screen (S5, shreds), or a hammermill with screen sizes of $15,10,5$, and $3 \mathrm{~mm}(\mathrm{C} 15, \mathrm{C} 10, \mathrm{C} 5$, and $\mathrm{C} 3$, chips).

\subsection{Substrate Particle Size and Shape Distribution}

For both particle width and particle length, the curves of particle size distribution (Figure 2), their percentile values, and the fractions (Table 4) showed four groups of miscanthus substrates in the ascending order of particle size as $\mathrm{C} 3<\mathrm{C} 5<(\mathrm{C} 10, \mathrm{C} 15, \mathrm{~S} 5)<\mathrm{FC}$. The curves of $\mathrm{C} 3$ and $\mathrm{C} 5$ materials (smallest processed screen sizes) were closer to those of peat and coir: $\mathrm{C} 3$ had a similar distribution of particle length to peat and coir with a difference in medium and coarse fractions, whereas C5 showed a similar distribution of particle width to coir. The distribution curves of C10, C15, and S5 were close with a small difference (Table 4). While C10 and S5 had a similar particle size distribution, C15 showed a difference in the 10th and 90th percentile, particularly in particle length (Table 4). Hammermilling miscanthus through a $15 \mathrm{~mm}$ screen (C15) produced longer particles (higher d90 value) compared to hammermilling through a $10 \mathrm{~mm}$ screen (C10). However, the C15 in this study also showed finer particles than $\mathrm{C} 10$, expressed as a smaller d10 value. The fraction of fine particles $(<0.5 \mathrm{~mm})$ in C15 was 5\% higher than that in C10, but non-significant (Table 4 ). The slight difference in fine particles between $\mathrm{C} 15$ and $\mathrm{C} 10$ indicated that hammermilling through a screen size from $10-15 \mathrm{~mm}$ showed a narrow deviation. The particle length curve of FC had a steep slope at size $30 \mathrm{~mm}$ because the measurement range of Camsizer ${ }^{\circledR}$ $\mathrm{P} 4$ is smaller than $30 \mathrm{~mm}$ and FC had approximately $8 \%$ of particle length greater than $30 \mathrm{~mm}$ (Figure 2). 

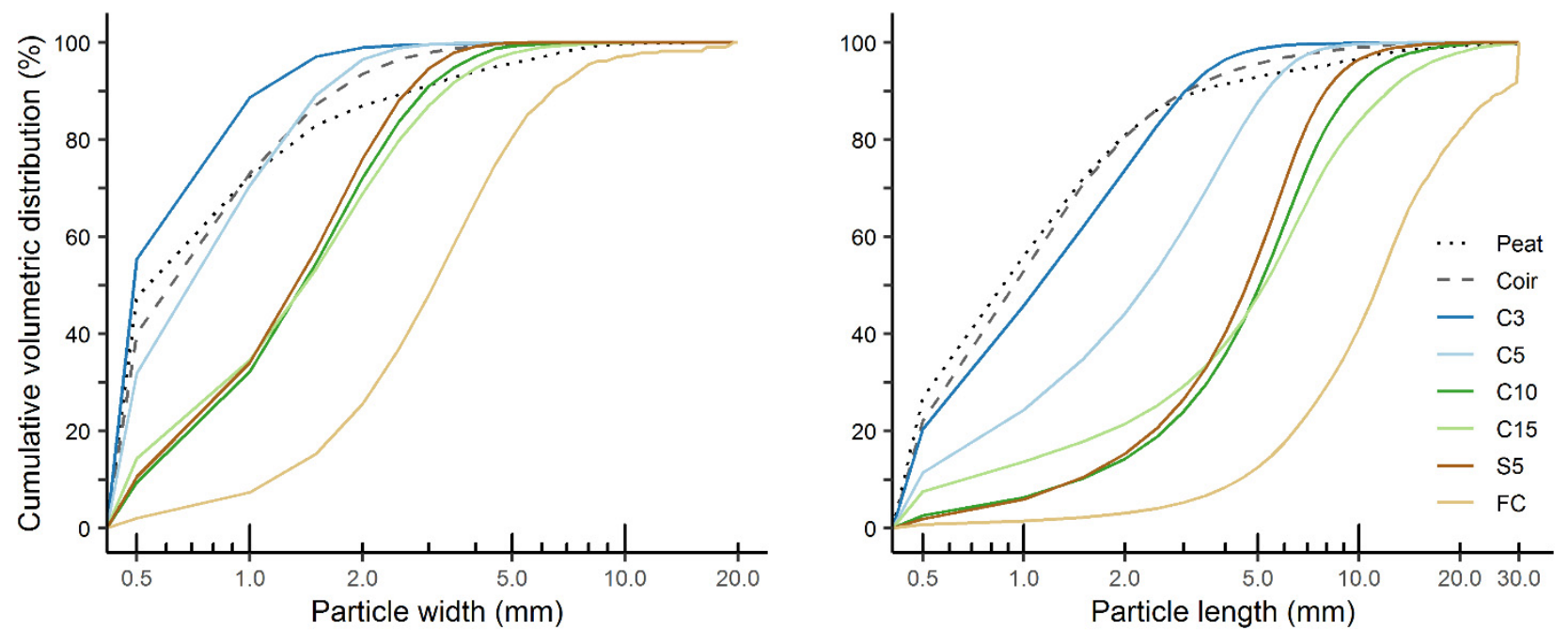

Figure 2. Volumetric distribution of particle size of peat, coir, and processed miscanthus substrates analyzed with dynamic image analysis. The curve represents for mean value of four replicates of each substrate. Miscanthus $\times$ giganteus was harvested with a forage harvester (FC, field-chips), then processed with a mechanical fraying facility through a 5-mm screen (S5, shreds) or a hammermill with screen sizes of 15, 10, 5, and $3 \mathrm{~mm}$ (C15, C10, C5, and C3 chips).

Table 4. Volume-based particle size parameters of peat, coir, and processed miscanthus substrates using dynamic image analysis.

\begin{tabular}{|c|c|c|c|c|c|c|c|c|}
\hline \multirow{2}{*}{ Substrate } & \multicolumn{3}{|c|}{ Fraction (\%) ${ }^{1}$} & \multicolumn{3}{|c|}{ Percentile Values $(\mathrm{mm})^{2}$} & \multirow{2}{*}{ Non-Uniformity ${ }^{3}$} & \multirow{2}{*}{$\begin{array}{l}\text { Specific Surface } \\
\qquad\left(1 \mathrm{~mm}^{-1}\right)^{4}\end{array}$} \\
\hline & Fine & Medium & Coarse & d10 & d50 & d90 & & \\
\hline \multicolumn{9}{|c|}{ Particle width } \\
\hline Peat & $47.5 \pm 6.6 \mathrm{~b}$ & $39.4 \pm 6.3 c$ & $13 \pm 0.4 \mathrm{e}$ & $0.16 \mathrm{~d}$ & $0.53 \mathrm{de}$ & $2.69 c$ & $4.3 \pm 0.3 \mathrm{a}$ & $16.3 \pm 2.4 \mathrm{a}$ \\
\hline Coir & $40.1 \pm 2.0 c$ & $53.4 \pm 1.8 \mathrm{~b}$ & $6.4 \pm 0.3 \mathrm{f}$ & $0.21 \mathrm{~d}$ & $0.61 \mathrm{~cd}$ & $1.68 \mathrm{~d}$ & $3.6 \pm 0.1 \mathrm{bc}$ & $12.7 \pm 0.6 \mathrm{~b}$ \\
\hline $\mathrm{C} 3$ & $55.4 \pm 4.0 \mathrm{a}$ & $43.6 \pm 4.1 c$ & $1.0 \pm 0.2 \mathrm{~h}$ & $0.17 \mathrm{~d}$ & $0.46 \mathrm{e}$ & $1.04 \mathrm{e}$ & $3.1 \pm 0.0 \mathrm{~cd}$ & $15.7 \pm 1.1 \mathrm{a}$ \\
\hline $\mathrm{C} 5$ & $31.9 \pm 2.2 \mathrm{~d}$ & $64.6 \pm 1.9 \mathrm{a}$ & $3.5 \pm 0.5 \mathrm{~g}$ & $0.23 \mathrm{~d}$ & $0.70 \mathrm{c}$ & $1.53 \mathrm{~d}$ & $3.6 \pm 0.2 \mathrm{~b}$ & $10.9 \pm 0.4 b$ \\
\hline $\mathrm{C} 10$ & $9.4 \pm 0.6 \mathrm{e}$ & $62.7 \pm 1.4 \mathrm{a}$ & $27.9 \pm 1.9 \mathrm{c}$ & $0.52 \mathrm{~b}$ & $1.39 \mathrm{~b}$ & $2.91 \mathrm{bc}$ & $3.2 \pm 0.0 \mathrm{bcd}$ & $5.2 \pm 0.1 c$ \\
\hline C15 & $14.3 \pm 1.3 \mathrm{e}$ & $54.6 \pm 0.4 b$ & $31.1 \pm 1.2 \mathrm{~b}$ & $0.37 \mathrm{c}$ & $1.41 \mathrm{~b}$ & $3.30 \mathrm{~b}$ & $4.6 \pm 0.4 \mathrm{a}$ & $6.7 \pm 0.4 \mathrm{c}$ \\
\hline S5 & $10.5 \pm 1.0 \mathrm{e}$ & $65.6 \pm 0.5 a$ & $23.9 \pm 0.8 \mathrm{~d}$ & $0.49 \mathrm{~b}$ & $1.33 \mathrm{~b}$ & $2.61 \mathrm{c}$ & $3.2 \pm 0.1 \mathrm{bcd}$ & $5.1 \pm 0.2 c$ \\
\hline $\mathrm{FC}$ & $2.1 \pm 0.6 \mathrm{f}$ & $23.5 \pm 0.7 \mathrm{~d}$ & $74.4 \pm 1.0 \mathrm{a}$ & $1.18 \mathrm{a}$ & $3.10 \mathrm{a}$ & $6.51 \mathrm{a}$ & $3.0 \pm 0.2 \mathrm{~d}$ & $2.3 \pm 0.2 \mathrm{~d}$ \\
\hline \multicolumn{9}{|c|}{ Particle length } \\
\hline Peat & $26.9 \pm 6.9 \mathrm{a}$ & $54.1 \pm 2.8 \mathrm{~b}$ & $19.0 \pm 4.7 \mathrm{f}$ & $0.27 \mathrm{~d}$ & $0.88 \mathrm{e}$ & $3.35 \mathrm{~d}$ & $4.1 \pm 0.3 c$ & $22.4 \pm 3.9 \mathrm{a}$ \\
\hline Coir & $22.1 \pm 2.0 \mathrm{a}$ & $58.5 \pm 1.0 \mathrm{a}$ & $19.4 \pm 1.2 \mathrm{f}$ & $0.31 \mathrm{~d}$ & $0.94 \mathrm{e}$ & $3.03 \mathrm{~d}$ & $3.8 \pm 0.1 \mathrm{~cd}$ & $14.6 \pm 0.8 c$ \\
\hline $\mathrm{C} 3$ & $20.4 \pm 3.2 \mathrm{a}$ & $53.4 \pm 0.7 \mathrm{~b}$ & $26.2 \pm 3.3 \mathrm{e}$ & $0.32 \mathrm{~d}$ & $1.11 \mathrm{e}$ & $3.02 \mathrm{~d}$ & $4.4 \pm 0.1 \mathrm{c}$ & $18.7 \pm 1.3 \mathrm{~b}$ \\
\hline $\mathrm{C} 5$ & $11.5 \pm 1.0 \mathrm{~b}$ & $32.7 \pm 0.9 c$ & $55.8 \pm 0.8 \mathrm{~d}$ & $0.45 \mathrm{~cd}$ & $2.32 \mathrm{~d}$ & $5.27 \mathrm{~d}$ & $6.5 \pm 0.5 b$ & $13.4 \pm 0.5 c$ \\
\hline $\mathrm{C} 10$ & $2.6 \pm 0.2 c$ & $11.7 \pm 0.8 \mathrm{~d}$ & $85.7 \pm 0.7 b$ & $1.47 \mathrm{~b}$ & $5.06 \mathrm{~b}$ & $9.50 \mathrm{c}$ & $3.9 \pm 0.1 \mathrm{~cd}$ & $6.5 \pm 0.2 \mathrm{~d}$ \\
\hline C15 & $6.6 \pm 0.9 \mathrm{bc}$ & $13.9 \pm 0.7 \mathrm{~d}$ & $78.5 \pm 1.7 \mathrm{c}$ & $0.68 c$ & $5.23 \mathrm{~b}$ & $12.29 \mathrm{~b}$ & $9.3 \pm 1.2 \mathrm{a}$ & $9.4 \pm 0.6 \mathrm{~d}$ \\
\hline S5 & $1.9 \pm 0.2 c$ & $13.4 \pm 0.4 \mathrm{~d}$ & $84.7 \pm 0.6 b$ & $1.45 \mathrm{~b}$ & $4.63 c$ & $7.95 c$ & $3.6 \pm 0.1 \mathrm{~cd}$ & $6.8 \pm 0.1 \mathrm{~d}$ \\
\hline FC & $0.8 \pm 0.3 c$ & $2.3 \pm 0.5 \mathrm{e}$ & $96.9 \pm 0.9 a$ & $4.39 \mathrm{a}$ & $11.38 \mathrm{a}$ & $26.92 \mathrm{a}$ & $3.0 \pm 0.2 \mathrm{~d}$ & $2.6 \pm 0.2 \mathrm{e}$ \\
\hline
\end{tabular}

${ }^{1}$ Particle size: fine $(<0.5 \mathrm{~mm})$, medium $(0.5-2.0 \mathrm{~mm})$, and coarse $(>2.0)[39]{ }^{2} \mathrm{~d} 10$, d50 and d90 represent the value of particle size when the portion of particles with a size smaller than that value is $10 \%, 50 \%$, and $90 \%$, respectively. ${ }^{3}$ Non-uniformity is d60/d10 (Camsizer's parameter: U3). ${ }^{4}$ Specific surface is the ratio of surface of all particles and volume of all particles (Camsizer's parameter: Sv. Different lower case letters indicate statistically significant differences in means among eight substrates at each substrate parameter in each column (Tukey's HSD, $p \leq 0.05$, mean \pm standard deviation, $\mathrm{n}=4$ ). Miscanthus $\times$ giganteus was harvested with a forage harvester (FC, field-chips), then processed with a mechanical fraying facility through a $5-\mathrm{mm}$ screen (S5, shreds) or a hammermill with screen sizes of 15, 10, 5, and $3 \mathrm{~mm}$ (C15, C10, C5, and C3, chips).

Non-uniformity coefficient indicates the homogeneity of particle size distribution. Peat and coir had similar non-uniformity coefficients in both width and length (Table 4). On the other hand, miscanthus substrates showed a different extent of non-uniformity in each 
dimension. Given smaller non-uniformity coefficients, the particle width of miscanthus substrates was more homogenous than particle length. The specific surface area showed the same grouping with reducing particle size and increasing specific surface area as peat $>$ coir $>$ C3 $>$ C5 $>(C 10, C 15$, S5) $>$ FC (Table 4).

Substrates showed different particle shape profiles as in the distribution curve (Figure 3) and the mean values at each size category (Table 5). Miscanthus substrates had more elongated particles than peat and coir, expressed as the aspect ratio. Among miscanthus substrates, only C3 showed less elongated shape, others had the same degree of elongation (Figure 3). In all substrates, the degree of elongation increased with the increase in particle size, which was expressed as the mean value of aspect ratio at each size category (Table 5).
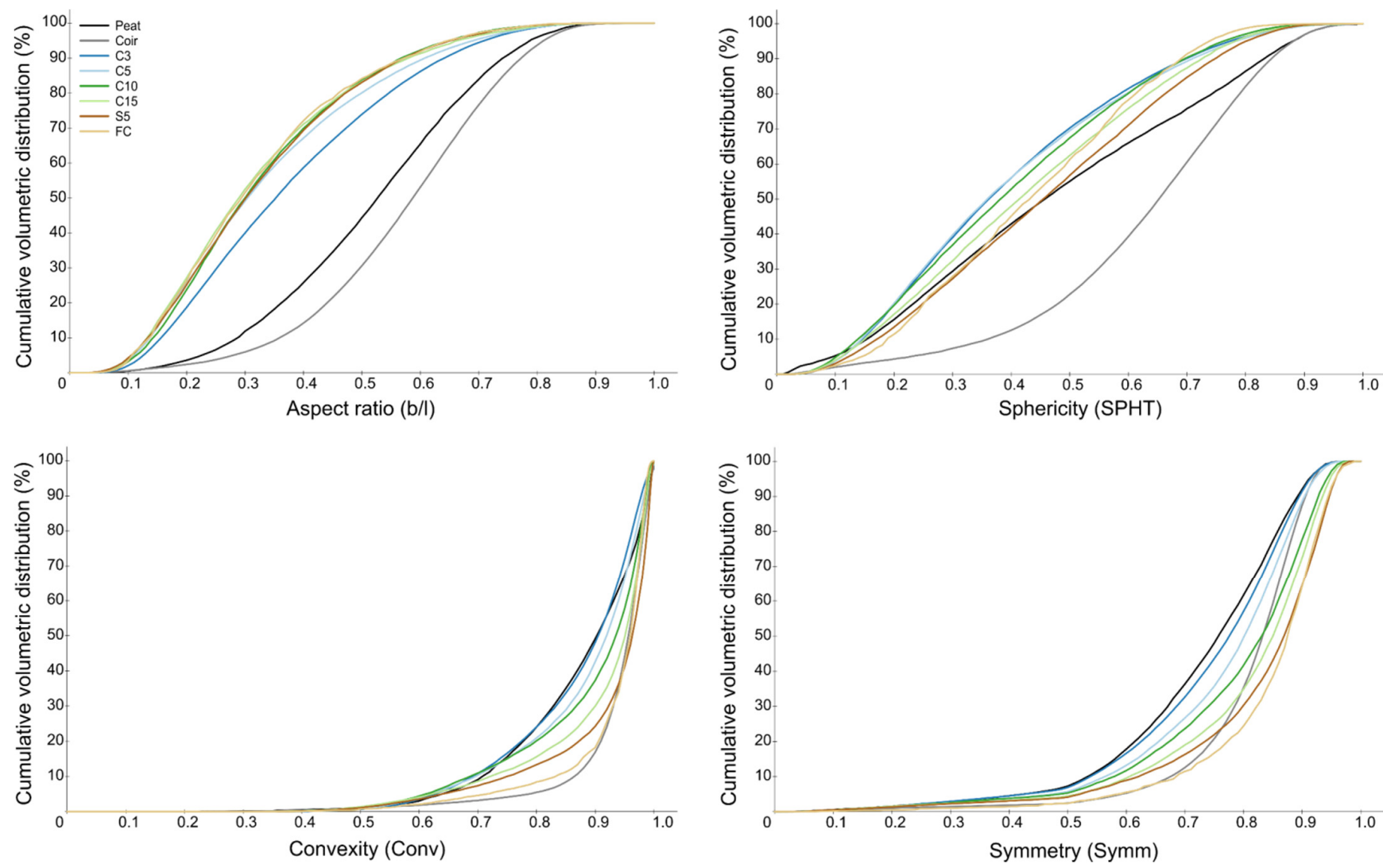

Figure 3. Volumetric distribution of particle shape of peat, coir, and processed miscanthus substrates analyzed with dynamic image analysis. The curve represents for one measurement of each substrate. Miscanthus $\times$ giganteus was harvested with a forage harvester (FC, field-chips), then processed with a mechanical fraying facility through a 5-mm screen (S5, shreds) or a hammermill with screen sizes of $15,10,5$, and $3 \mathrm{~mm}(\mathrm{C} 15, \mathrm{C} 10, \mathrm{C} 5$, and C3, chips).

The sphericity parameter (SPHT) describes the sphere shape, and it also indicates the roughness of particle surface [43]. The higher the SPHT values, the smoother the particle surfaces. Among the tested substrates, coir had more particles with a smoother surface than peat and miscanthus (Figure 3, Table 5). The shredded S5 showed a less rough surface than hammermilled miscanthus substrates, particularly in coarse particles. The convexity (conv), another indicator for surface roughness, also showed the same pattern for miscanthus substrates. Tested substrates had rather symmetrical particles. 
Table 5. Volume-based particle shape parameters of peat, coir and processed miscanthus substrates using dynamic image analysis.

\begin{tabular}{|c|c|c|c|c|c|c|c|c|c|}
\hline \multirow{2}{*}{ Substrate } & \multicolumn{3}{|c|}{ Aspect Ratio (b/l) } & \multicolumn{3}{|c|}{ Sphericity (SPHT) } & \multicolumn{3}{|c|}{ Symmetry (Symm) } \\
\hline & Fine & Medium & Coarse & Fine & Medium & Coarse & Fine & Medium & Coarse \\
\hline \multicolumn{10}{|c|}{ Size fractions based on particle width } \\
\hline Peat & $0.51 \mathrm{~b}$ & $0.57 \mathrm{~b}$ & $0.58 \mathrm{a}$ & $0.47 \mathrm{~d}$ & $0.50 \mathrm{~b}$ & $0.46 \mathrm{ab}$ & $0.70 \mathrm{e}$ & $0.72 \mathrm{c}$ & $0.73 \mathrm{bc}$ \\
\hline Coir & $0.62 \mathrm{a}$ & $0.60 \mathrm{a}$ & $0.59 \mathrm{a}$ & $0.69 \mathrm{a}$ & $0.63 \mathrm{a}$ & $0.48 \mathrm{a}$ & $0.82 \mathrm{a}$ & $0.82 \mathrm{a}$ & $0.81 \mathrm{a}$ \\
\hline $\mathrm{C} 3$ & $0.49 \mathrm{bc}$ & $0.48 \mathrm{c}$ & $0.52 \mathrm{~b}$ & $0.50 \mathrm{~cd}$ & $0.33 \mathrm{e}$ & $0.10 \mathrm{~d}$ & $0.75 \mathrm{~d}$ & $0.67 \mathrm{~d}$ & $0.62 \mathrm{~d}$ \\
\hline $\mathrm{C} 5$ & $0.47 \mathrm{~cd}$ & $0.40 \mathrm{~d}$ & $0.49 \mathrm{~b}$ & $0.53 \mathrm{bc}$ & $0.39 \mathrm{~d}$ & $0.25 c$ & $0.78 \mathrm{c}$ & $0.72 \mathrm{c}$ & $0.62 \mathrm{~d}$ \\
\hline C10 & $0.42 \mathrm{e}$ & $0.34 \mathrm{e}$ & $0.48 \mathrm{bc}$ & $0.52 \mathrm{bc}$ & $0.41 \mathrm{~cd}$ & $0.34 \mathrm{bc}$ & $0.80 \mathrm{bc}$ & $0.77 \mathrm{~b}$ & $0.70 \mathrm{~cd}$ \\
\hline C15 & $0.49 \mathrm{bc}$ & $0.33 \mathrm{f}$ & $0.43 \mathrm{~cd}$ & $0.58 \mathrm{~b}$ & $0.42 \mathrm{~cd}$ & $0.26 \mathrm{c}$ & $0.80 \mathrm{ab}$ & $0.78 \mathrm{~b}$ & $0.65 \mathrm{~cd}$ \\
\hline S5 & $0.37 \mathrm{f}$ & $0.35 \mathrm{e}$ & $0.52 \mathrm{~b}$ & $0.47 \mathrm{~d}$ & $0.46 \mathrm{bc}$ & $0.47 \mathrm{a}$ & $0.79 \mathrm{bc}$ & $0.80 \mathrm{a}$ & $0.75 a b$ \\
\hline FC & $0.45 \mathrm{de}$ & $0.32 \mathrm{~g}$ & $0.41 \mathrm{~d}$ & $0.53 \mathrm{bc}$ & $0.42 \mathrm{~cd}$ & $0.40 \mathrm{ab}$ & $0.80 \mathrm{~b}$ & $0.81 \mathrm{a}$ & $0.77 \mathrm{ab}$ \\
\hline \multicolumn{10}{|c|}{ Size fractions based on particle length } \\
\hline Peat & $0.49 \mathrm{~cd}$ & $0.35 \mathrm{~b}$ & $0.31 \mathrm{a}$ & $0.59 \mathrm{~cd}$ & $0.39 \mathrm{~d}$ & 0.19 de & $0.76 \mathrm{~d}$ & $0.66 \mathrm{e}$ & $0.50 \mathrm{e}$ \\
\hline Coir & $0.60 \mathrm{a}$ & $0.47 \mathrm{a}$ & $0.23 \mathrm{~b}$ & $0.74 \mathrm{a}$ & $0.56 \mathrm{a}$ & $0.20 \mathrm{~d}$ & $0.84 \mathrm{a}$ & $0.76 \mathrm{~b}$ & $0.60 \mathrm{~d}$ \\
\hline $\mathrm{C} 3$ & $0.47 \mathrm{de}$ & $0.27 \mathrm{~d}$ & $0.28 \mathrm{a}$ & $0.58 \mathrm{~d}$ & $0.37 \mathrm{e}$ & $0.15 \mathrm{e}$ & $0.78 \mathrm{c}$ & $0.72 \mathrm{~d}$ & $0.65 \mathrm{c}$ \\
\hline $\mathrm{C} 5$ & $0.46 \mathrm{de}$ & $0.27 \mathrm{~d}$ & $0.16 \mathrm{c}$ & $0.61 \mathrm{~cd}$ & $0.40 \mathrm{~d}$ & $0.22 \mathrm{~cd}$ & $0.81 \mathrm{~b}$ & $0.74 \mathrm{c}$ & $0.72 \mathrm{~b}$ \\
\hline $\mathrm{C} 10$ & 0.46 de & $0.28 \mathrm{~d}$ & $0.19 c$ & $0.63 \mathrm{bc}$ & $0.43 c$ & $0.24 \mathrm{bc}$ & $0.83 \mathrm{ab}$ & $0.76 \mathrm{ab}$ & $0.73 \mathrm{~b}$ \\
\hline C15 & $0.50 \mathrm{~b}$ & $0.27 \mathrm{~d}$ & $0.18 \mathrm{c}$ & $0.66 \mathrm{~b}$ & $0.42 \mathrm{c}$ & $0.20 \mathrm{~cd}$ & $0.83 \mathrm{ab}$ & $0.76 \mathrm{~b}$ & $0.69 \mathrm{c}$ \\
\hline S5 & $0.45 \mathrm{e}$ & $0.28 \mathrm{~d}$ & $0.15 c$ & $0.61 \mathrm{~cd}$ & $0.42 \mathrm{c}$ & $0.26 \mathrm{~b}$ & $0.83 \mathrm{ab}$ & $0.76 \mathrm{~b}$ & $0.77 \mathrm{a}$ \\
\hline FC & $0.50 \mathrm{bc}$ & $0.32 \mathrm{c}$ & $0.22 \mathrm{~b}$ & $0.63 \mathrm{bc}$ & $0.46 \mathrm{~b}$ & $0.32 \mathrm{a}$ & $0.82 \mathrm{ab}$ & $0.76 \mathrm{a}$ & $0.79 \mathrm{a}$ \\
\hline
\end{tabular}

Particle size: fine $(<0.5 \mathrm{~mm})$, medium $(0.5-2.0 \mathrm{~mm})$, and coarse ( $>2.0)$ [39]. Different lower case letters indicate statistically significant differences in means among eight substrates at each substrate parameter in each column (Tukey's HSD, $p \leq 0.05, \mathrm{n}=4$ ). Miscanthus $\times$ giganteus was harvested with a forage harvester (FC, field-chips), then processed with a mechanical fraying facility through a $5-\mathrm{mm}$ screen (S5, shreds) or a hammermill with screen sizes of $15,10,5$, and $3 \mathrm{~mm}(\mathrm{C} 15, \mathrm{C} 10, \mathrm{C} 5$, and $\mathrm{C} 3$, chips).

\subsection{Substrate Hydrological Properties: Porosity and Wettability \\ 3.3.1. Porosity}

The porosity of miscanthus substrates showed similar grouping behavior as those in particle size. In the descending order of particle size, miscanthus substrates showed an increased WHC and a reduced air-filled porosity (AFP). Miscanthus substrates had a higher AFP compared to peat and coir. Miscanthus substrate groupings showed a descending order of WHC as C3 > C5 > (C10, C15, S5) > FC (Figure 4). As the finest particle, C3 had a similar WHC to commercial peat substrate, and it was slightly lower than the commercial coir tested. Regarding WHC, miscanthus substrates, except FC, provided WHC in the recommended range of $45-65 \%$ for nursery substrates [53]. Except C3, other miscanthus substrates had an AFP higher than the recommended range of $10-30 \%$.

\subsubsection{Wettability}

According to the wettability classes described by Michel et al. (2017) [54], our data showed that the two commercial coir and peat substrates used in these experiments were hydrophilic and miscanthus substrates that had low and reversible risk of hydrophobicity (Table 6). It should be noted that the commercial peat used in these tests was amended with $30 \%$ clay to improve its wettability. Tests were not performed on $100 \%$ pure peat moss with no amendments. Miscanthus substrates at higher initial moisture could recover their water contents close to their WHC, but those at lower initial moisture recovered quite slowly but reversibly. As hydrophilic material, coir at different IMC values reached $90 \%$ of its maximum water retention after the first hydration event (Figures 5 and 6). Wettability of peat reduces at low moisture content, but amendment of $30 \%$ clay as in this commercial peat substrate improved wettability of peat. Based on hydration speed, initial hydration efficiency, and retention efficiency, miscanthus substrates could be grouped according to ascending order of risk of hydrophobicity as C3 $<\mathrm{C} 5<(\mathrm{C} 10$ and $\mathrm{C} 15)<(\mathrm{S} 5$ and FC) (Table 6). In general, finer miscanthus substrates showed a lower risk of hydrophobicity, except the shredded S5. 


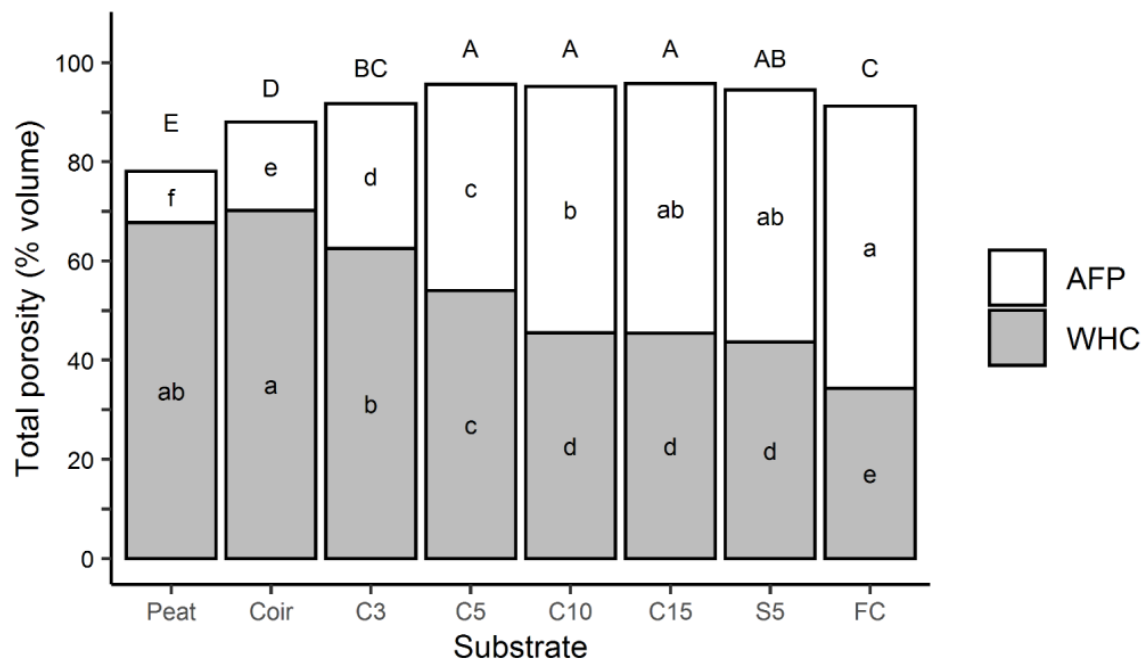

Figure 4. Porosity of peat, coir, and processed miscanthus substrates: water holding capacity (WHC), air-filled porosity (AFP), and total porosity (as the total height of stacked bars of WHC and AFP). Different lower case and capital letters indicate statistically significant differences in means among eight substrates at each substrate parameter WHC, AFP, and total porosity, respectively (Tukey's HSD, $p \leq 0.05, \mathrm{n}=8$ ). Miscanthus $\times$ giganteus was harvested with a forage harvester (FC, field-chips), then processed with a mechanical fraying facility through a 5-mm screen (S5, shreds) or a hammermill with screen sizes of $15,10,5$, and $3 \mathrm{~mm}$ (C15, C10, C5, and C3, chips).

Table 6. Hydration efficiency of peat, coir, and processed miscanthus substrates.

\begin{tabular}{|c|c|c|c|c|c|c|}
\hline Substrate & IMC $^{1}$ & $\mathrm{HS}^{2}$ & HE1 $^{3}$ & $\mathrm{RE}^{4}$ & Swelling 5 & Risk Level of Hydrophobicity ${ }^{6}$ \\
\hline \multirow[t]{4}{*}{ Peat } & 67 & 1 & $0.96 \mathrm{a}$ & $0.90 \mathrm{~b}$ & $0 \pm 0$ & \multirow{4}{*}{$\begin{array}{c}\text { no risk of hydrophobicity, but less } \\
\text { hydrophilic than coir }\end{array}$} \\
\hline & 50 & 1 & $0.94 \mathrm{a}$ & $0.92 \mathrm{~b}$ & $0 \pm 0$ & \\
\hline & 25 & 2 & $0.71 \mathrm{~b}$ & $1.03 \mathrm{a}$ & $2.6 \pm 2.1$ & \\
\hline & non-wet & 3 & $0.56 \mathrm{~b}$ & $0.81 \mathrm{c}$ & $-1.2 \pm 2.4$ & \\
\hline \multirow[t]{4}{*}{ Coir } & 67 & 1 & $0.91 \mathrm{a}$ & $0.91 \mathrm{~b}$ & $0 \pm 0$ & \multirow{4}{*}{ no risk of hydrophobicity } \\
\hline & 50 & 1 & $0.92 \mathrm{a}$ & $0.93 \mathrm{~b}$ & $0 \pm 0$ & \\
\hline & 25 & 2 & $0.83 \mathrm{a}$ & $1.04 \mathrm{a}$ & $6.0 \pm 1.1$ & \\
\hline & non-wet & 3 & $0.58 \mathrm{~b}$ & $0.94 \mathrm{~b}$ & $0.8 \pm 1.7$ & \\
\hline \multirow[t]{4}{*}{$\mathrm{C} 3$} & 67 & 2 & $0.83 a$ & $0.90 \mathrm{~b}$ & $0 \pm 0$ & \multirow{4}{*}{$\begin{array}{l}\text { low and reversible risk, } \\
\text { least hydrophobic among tested } \\
\text { miscanthus substrates }\end{array}$} \\
\hline & 50 & 2 & $0.81 \mathrm{a}$ & $0.75 \mathrm{c}$ & $0 \pm 0$ & \\
\hline & 25 & 3 & $0.63 \mathrm{~b}$ & $0.87 \mathrm{~b}$ & $0 \pm 0$ & \\
\hline & non-wet & 1 & $0.94 \mathrm{a}$ & $1.02 \mathrm{a}$ & $1.2 \pm 1.4$ & \\
\hline \multirow[t]{4}{*}{ C5 } & 67 & 3 & $0.82 \mathrm{a}$ & $0.91 \mathrm{~b}$ & $0 \pm 0$ & \multirow{4}{*}{$\begin{array}{l}\text { low and reversible risk, } \\
\text { 2nd less hydrophobic among tested } \\
\text { miscanthus substrates }\end{array}$} \\
\hline & 50 & 3 & $0.77 \mathrm{a}$ & $0.83 \mathrm{~b}$ & $0 \pm 0$ & \\
\hline & 25 & 3 & $0.52 \mathrm{~b}$ & $0.86 \mathrm{~b}$ & $0 \pm 0$ & \\
\hline & non-wet & 2 & $0.78 \mathrm{a}$ & $1.00 \mathrm{a}$ & $2.4 \pm 1.7$ & \\
\hline \multirow[t]{4}{*}{ C10 } & 67 & 2 & $0.85 \mathrm{a}$ & $0.93 \mathrm{a}$ & $0 \pm 0$ & \multirow{4}{*}{$\begin{array}{l}\text { low and reversible risk, } \\
\text { 3rd hydrophobic among tested } \\
\text { miscanthus substrates }\end{array}$} \\
\hline & 50 & 3 & $0.75 \mathrm{ab}$ & $0.85 \mathrm{~b}$ & $0 \pm 0$ & \\
\hline & 25 & 3 & $0.55 c$ & $0.87 \mathrm{~b}$ & $0 \pm 0$ & \\
\hline & non-wet & 2 & $0.64 \mathrm{bc}$ & $0.94 \mathrm{a}$ & $5.1 \pm 3.0$ & \\
\hline \multirow[t]{4}{*}{ C15 } & 67 & 2 & $0.85 a$ & $0.92 \mathrm{ab}$ & $0 \pm 0$ & \multirow{4}{*}{$\begin{array}{l}\text { low and reversible risk, } \\
\text { 3rd hydrophobic among tested } \\
\text { miscanthus substrates }\end{array}$} \\
\hline & 50 & 2 & $0.81 \mathrm{a}$ & $0.88 \mathrm{ab}$ & $0 \pm 0$ & \\
\hline & 25 & 3 & $0.45 c$ & $0.86 \mathrm{~b}$ & $0 \pm 0$ & \\
\hline & non-wet & 3 & $0.59 \mathrm{~b}$ & $0.93 \mathrm{a}$ & $5.5 \pm 2.5$ & \\
\hline
\end{tabular}


Table 6. Cont.

\begin{tabular}{ccccccc}
\hline Substrate & IMC $^{\mathbf{1}}$ & HS $^{\mathbf{2}}$ & HE1 $^{\mathbf{3}}$ & $\mathbf{R E}^{\mathbf{4}}$ & Swelling $^{\mathbf{5}}$ & Risk Level of Hydrophobicity $^{\mathbf{6}}$ \\
\hline S5 & 67 & 2 & $0.86 \mathrm{a}$ & $0.90 \mathrm{ab}$ & $0 \pm 0$ & low and reversible risk, \\
& 50 & 3 & $0.75 \mathrm{a}$ & $0.84 \mathrm{~b}$ & $0 \pm 0$ & 4th hydrophobic among tested \\
miscanthus substrates
\end{tabular}

${ }^{1}$ Initial moisture content. ${ }^{2}$ Hydration speed (HS): number of hydration events applied until substrate reaches $90 \%$ its maximum water retention. ${ }^{3}$ Hydration efficiency after the first hydration event (HE1). ${ }^{4}$ Retention efficiency (RE): the ratio of maximum water retention to water holding capacity. ${ }^{5}$ Swelling (\%): proportion of swollen volume after 10 hydration events to the initial volume of substrate column. ${ }^{6}$ Risk of level of hydrophobicity according to the category described by Michel et al., 2017 [54]. Different lower case letters indicate statistically significant differences in means among four initial moisture content at each substrate in each column (Tukey's HSD, $p \leq 0.05$, mean \pm standard deviation, $\mathrm{n}=4$ ). Miscanthus $\times$ giganteus was harvested with a forage harvester (FC, field-chips), then processed with a mechanical fraying facility through a 5-mm screen (S5, shreds) or a hammermill with screen sizes of 15, 10, 5, and $3 \mathrm{~mm}$ (C15, C10, C5, and C3, chips).
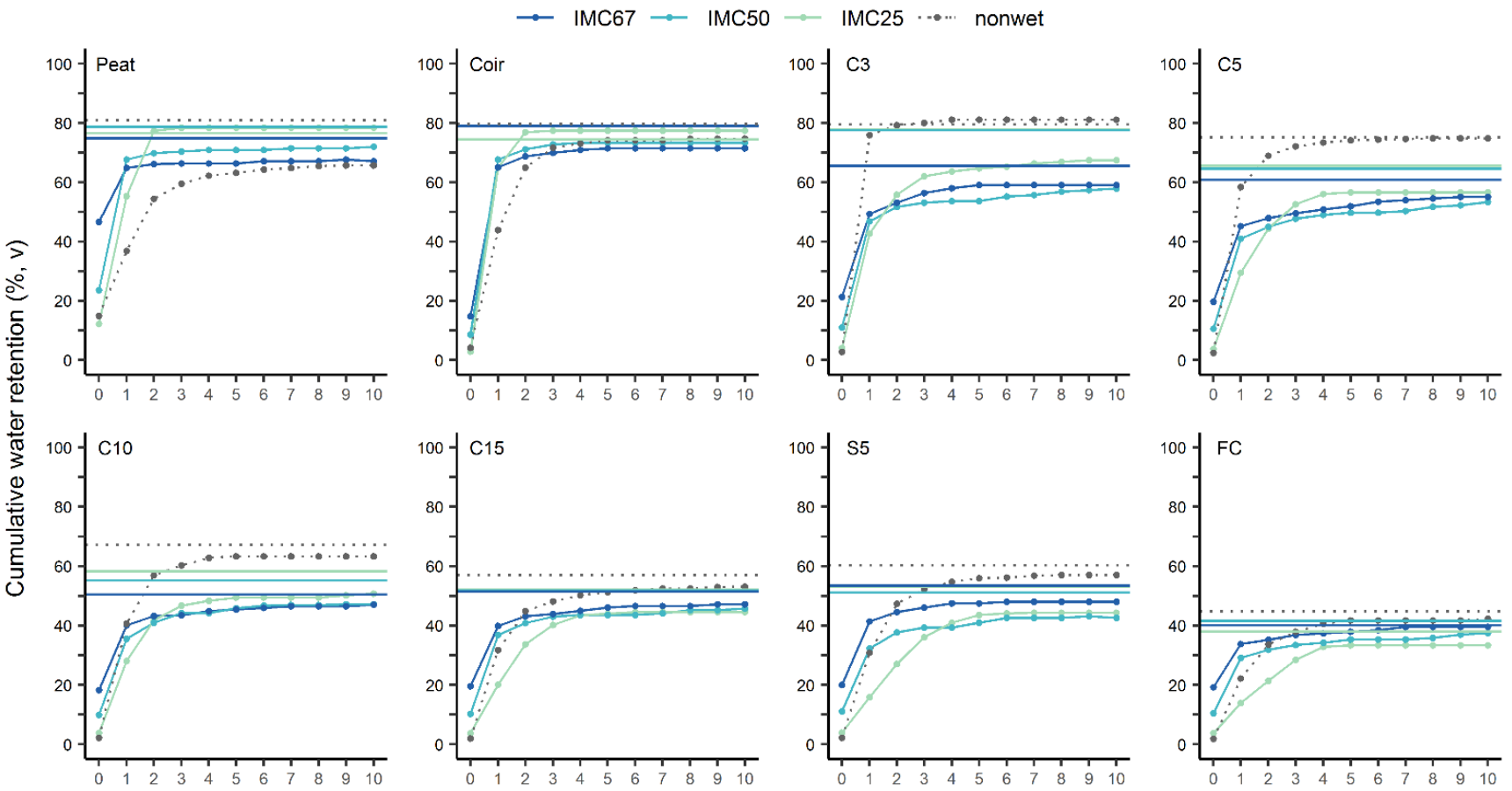

Hydration event

Figure 5. Hydration curves of peat, coir, and six processed miscanthus substrates at different initial moisture content $(67 \% \mathrm{w}, 50 \% \mathrm{w}, 25 \% \mathrm{w}$, and non-wet). The curves are cumulative water retention (volume) after 10 successive hydration events. The reference lines are water holding capacity of the substrates. Each data point is a mean of 4 replicates. Miscanthus $\times$ giganteus was harvested with a forage harvester (FC, field-chips), then processed with a mechanical fraying facility through a 5-mm screen (S5, shreds) or a hammermill with screen sizes of 15, 10, 5, and $3 \mathrm{~mm}$ (C15, C10, C5, and C3, chips). Commercial peat substrate amended with $30 \%$ clay. 


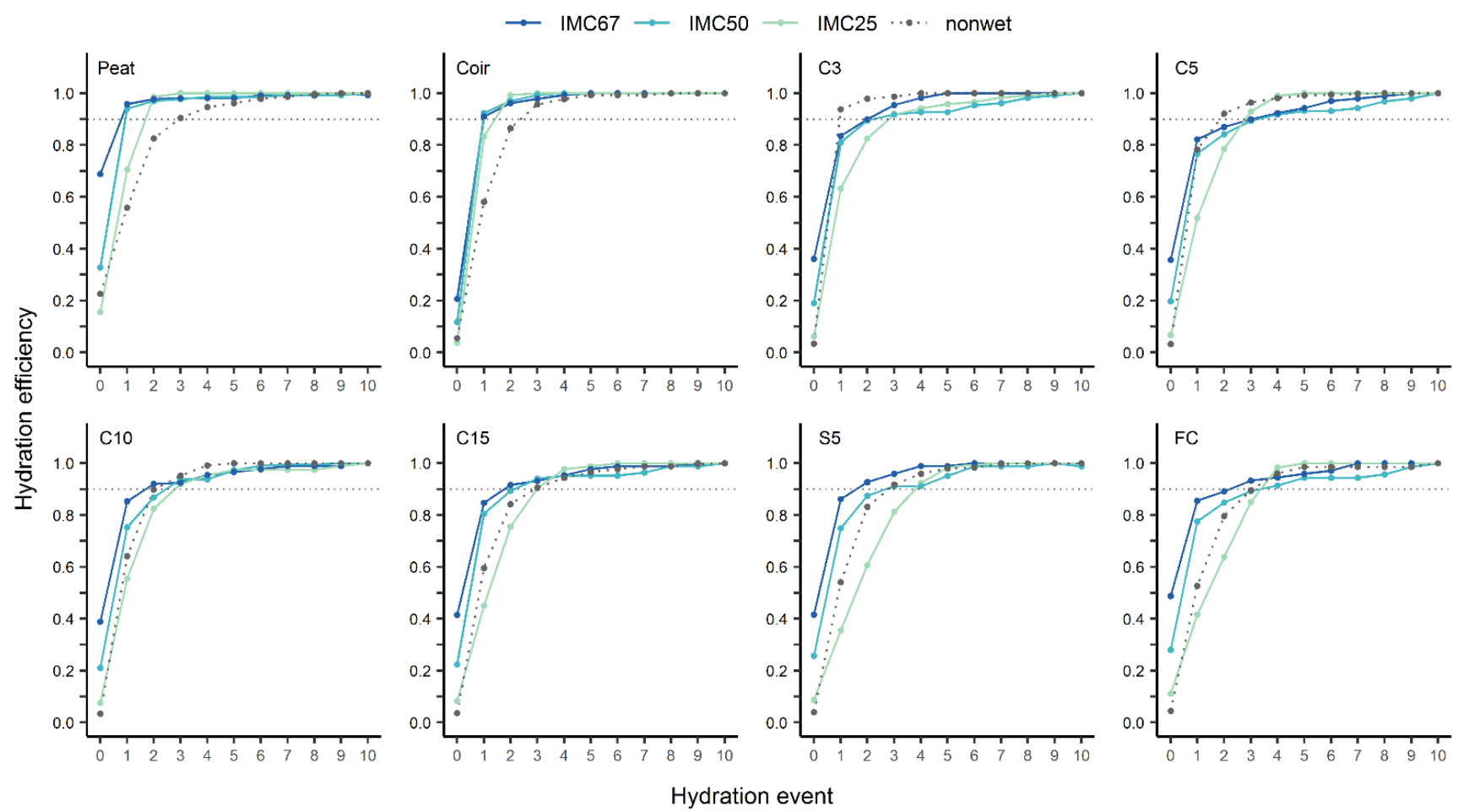

Figure 6. Hydration efficiency curves of peat, coir, and six processed miscanthus substrates at different initial moisture content $(67 \% \mathrm{w}, 50 \% \mathrm{w}, 25 \% \mathrm{w}$, and non-wet). In each curve, each point represents for the ratio of cumulative water retention at each event to the maximum water retention within 10 events (hydration efficiency). The dotted reference line represents for hydration efficiency of $90 \%$. Each data point is a mean of 4 replicates. Miscanthus $\times$ giganteus was harvested with a forage harvester (FC, field-chips), then processed with a mechanical fraying facility through a 5-mm screen (S5, shreds) or a hammermill with screen sizes of 15, 10, 5, and $3 \mathrm{~mm}$ (C15, C10, C5, and C3, chips). Commercial peat substrate amended with $30 \%$ clay.

The hydration curves of non-wet miscanthus behaved differently compared to nonwet peat and coir (Figures 5 and 6). Although the non-wet peat and coir had a higher IMC than $25 \%$, the non-wet materials reached their maximum water retention slower than the IMC25. Contrarily, the non-wet miscanthus with lower initial moisture content $(10 \%, \mathrm{w})$ reached their maximum water retention faster than their IMC25 (even for finer substrates such as C3 and C5, the non-wet material retained water as quick as their IMC67 and ICM50). This could be possibly explained by the higher packing bulk density of non-wet miscanthus (Supplementary Figure S2) or potentially a hysteretic effect of miscanthus substrates [55].

Substrate swelling, i.e., an increase in the height of the substrate column after 10 hydration events was observed at IMC25 for both peat and coir, which was expected due to the moisture content not being adequate for the testing procedure but not in any of the miscanthus treatments except FC (Table 6). This could be explained by the larger particle size of FC compared to other miscanthus substrates. The expanded particles of FC might not fit into the space between particles, while smaller miscanthus substrates could find their places in those spaces, resulting in a difference in substrate swelling. It was also observed in non-wet miscanthus substrates that swelling increased as particle size decreased.

\section{4. $\mathrm{pH}$ Buffering Capacity}

Changes in substrate $\mathrm{pH}$ to the amount of proton added strongly fitted a linear regression model $\left(p \leq 0.001, R^{2}>0.90\right)$ (Figure 7). From those linear regression equations, calculated $\mathrm{pH}$ buffering capacity showed that miscanthus had lower buffering capacity than peat, coir, and several compost substrates reported in literature with minimum difference of 
$0.03,0.1$, and $0.2 \mathrm{~mol} \mathrm{H}^{+} \mathrm{kg}^{-1}$ substrate $\mathrm{pH}$ unit ${ }^{-1}$, respectively (Table 7). Tested miscanthus substrates showed a similar value of $\mathrm{pH}$ buffering capacity, approximately $0.1 \mathrm{~mol}$ proton was needed to reduce one $\mathrm{pH}$ unit of one $\mathrm{kg}$ of substrate. Thus, modifying substrate morphology by processing did not alter $\mathrm{pH}$ buffering capacity of miscanthus treatments.

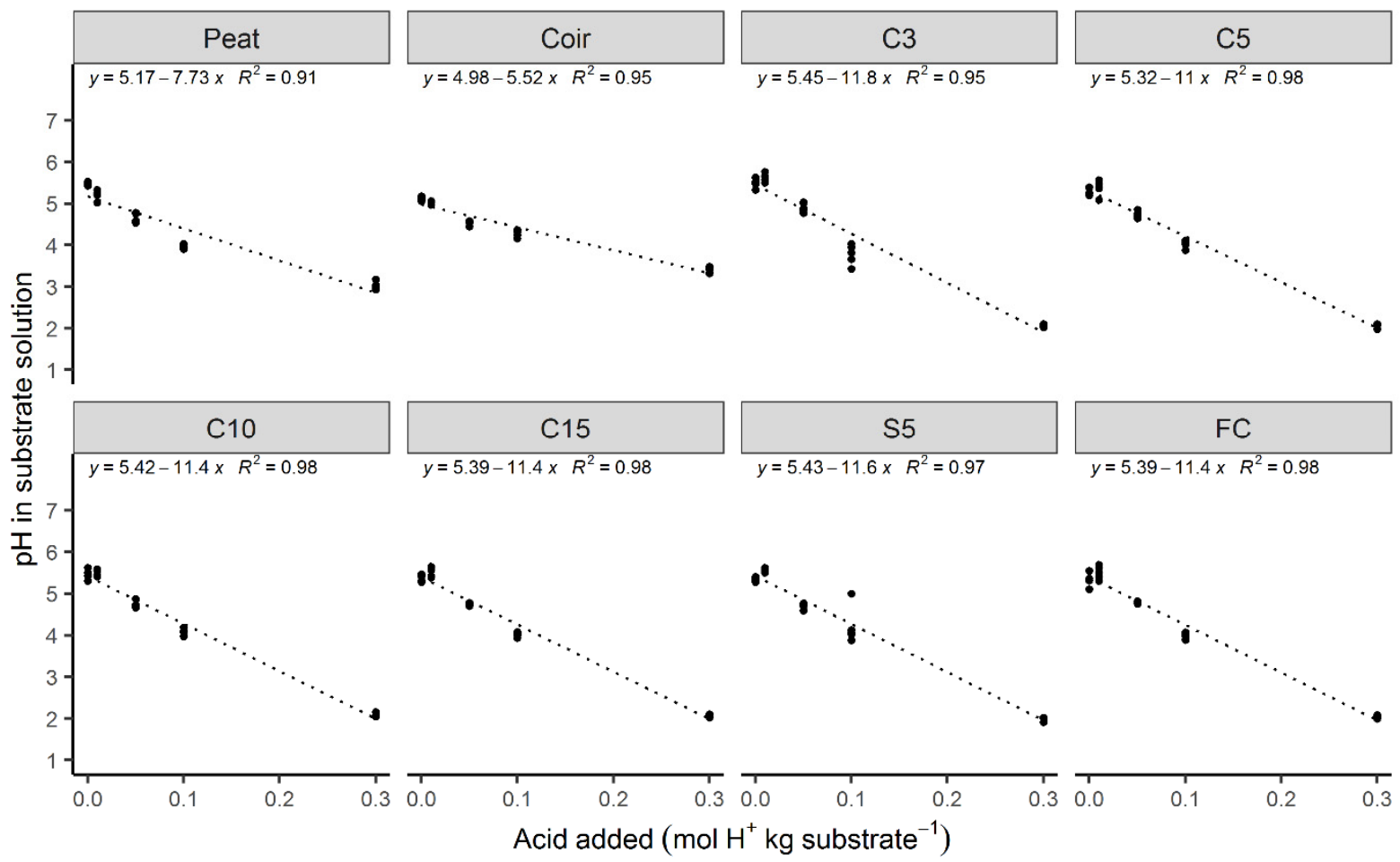

Figure 7. Linear regression for the determination of $\mathrm{pH}$ buffering capacity of peat, coir, and six processed miscanthus substrates. Each point represents for one sample. For each substrate at each proton concentration, there are 5 replicates. Miscanthus $\times$ giganteus was harvested with a forage harvester (FC, field-chips), then processed with a mechanical fraying facility through a 5-mm screen (S5, shreds) or a hammermill with screen sizes of 15, 10, 5, and $3 \mathrm{~mm}(\mathrm{C} 15, \mathrm{C} 10, \mathrm{C} 5$, and C3, chips).

Table 7. Initial $\mathrm{pH}$ and $\mathrm{pH}$ buffering capacity of peat, coir, and six processed miscanthus substrates.

\begin{tabular}{|c|c|c|}
\hline Substrate & Initial $\mathrm{pH}$ & $\begin{array}{c}\text { pH Buffering Capacity } \\
{\left(\mathrm{mol} \mathrm{H}^{+} \mathrm{kg} \mathrm{Substrate}^{-1} \mathrm{pH}_{\text {unit }}{ }^{-1}\right)}^{1}\end{array}$ \\
\hline Peat & 6.6 & 0.13 \\
\hline Coir & 6.7 & 0.18 \\
\hline $\mathrm{C} 3$ & 6.2 & 0.08 \\
\hline $\mathrm{C} 5$ & 6.3 & 0.10 \\
\hline $\mathrm{C} 10$ & 6.3 & 0.09 \\
\hline C15 & 6.3 & 0.09 \\
\hline S5 & 6.2 & 0.09 \\
\hline $\mathrm{FC}$ & 6.3 & 0.09 \\
\hline $\begin{array}{c}\text { Compost } \\
\text { (different component) }\end{array}$ & $6.4-8.8$ & $0.29-0.45[48]$ \\
\hline
\end{tabular}

${ }_{1}^{1} \mathrm{pH}$ buffering capacity $=-1$ /slope (slope as fitted slope of linear regression in Figure 6 ). Miscanthus $\times$ giganteus was harvested with a forage harvester (FC, field-chips), then processed with a mechanical fraying facility through a 5 -mm screen (S5, shreds) or a hammermill with screen sizes of $15,10,5$, and $3 \mathrm{~mm}$ (C15, C10, C5, and C3, chips).

\subsection{N Immobilization}

All tested substrates showed $\mathrm{N}$ immobilization at different values (Table 8). The NDI was calculated with the $\mathrm{N}$ rate of $300 \mathrm{mg} \mathrm{N} \mathrm{L}^{-1}$ as N immobilization did not occur in the $\mathrm{N}$ rate of $0 \mathrm{mg} \mathrm{N} \mathrm{L}^{-1}$ due to the absence of $\mathrm{N}$ in the system to activate microbial activity. Peat 
had minimal $\mathrm{N}$ immobilization (NDI $=0.9$ ), then coir with an NDI of 0.6. All miscanthus had a high $\mathrm{N}$ immobilization (NDI from 0.2-0.4), with no difference among C3, C5, C10, $\mathrm{C} 15$, and S5. The highest $\mathrm{N}$ immobilization occurred in coarse FC, which is likely due to it having the lowest $\mathrm{NO}_{3}$ concentration at day 0 . The amount of $\mathrm{NO}_{3}$ concentration in extract solution at day 0 increased with reducing particle size due to changes in WHC. Moreover, the $\mathrm{pH}$ in the extract solution of miscanthus substrates increased approximately 0.5 unit after 4 days, while the $\mathrm{pH}$ in the extract solution of peat and coir did not change (Table 8).

Table 8. Nitrogen drawdown index of peat, coir, and six processed miscanthus substrates.

\begin{tabular}{cccccc}
\hline \multirow{2}{*}{ Substrate } & \multicolumn{2}{c}{$\begin{array}{c}\mathbf{N O}_{3} \text { Concentration in } \\
\text { Extract Solution }\left(\mathbf{m g ~ L}^{-1}\right)\end{array}$} & \multicolumn{2}{c}{$\begin{array}{c}\text { pH in } \\
\text { Extract Solution }\end{array}$} & NDI At Day 4 ${ }^{\mathbf{1}}$ \\
\cline { 2 - 5 } & Day 0 & Day 4 & Day 0 & Day 4 & \\
\cline { 2 - 5 } Peat & $294.0 \pm 31.6 \mathrm{bcd}$ & $260.8 \pm 19.7 \mathrm{a}$ & $6.5 \pm 0.1 \mathrm{~b}$ & $6.7 \pm 0.1 \mathrm{c}$ & $0.89 \pm 0.12 \mathrm{a}$ \\
Coir & $449.0 \pm 60.0 \mathrm{a}$ & $261.0 \pm 14.9 \mathrm{a}$ & $6.6 \pm 0.2 \mathrm{~b}$ & $6.7 \pm 0.2 \mathrm{c}$ & $0.59 \pm 0.11 \mathrm{~b}$ \\
C3 & $397.5 \pm 32.7 \mathrm{ab}$ & $174.3 \pm 12.8 \mathrm{~b}$ & $7.1 \pm 0.1 \mathrm{a}$ & $7.6 \pm 0.1 \mathrm{ab}$ & $0.44 \pm 0.07 \mathrm{~b}$ \\
C5 & $367.3 \pm 110.7 \mathrm{abc}$ & $145.8 \pm 5.3 \mathrm{bc}$ & $7.2 \pm 0.1 \mathrm{a}$ & $7.7 \pm 0 \mathrm{ab}$ & $0.43 \pm 0.13 \mathrm{bc}$ \\
C10 & $296.3 \pm 61.6 \mathrm{bcd}$ & $113.5 \pm 22.9 \mathrm{~cd}$ & $7.1 \pm 0.1 \mathrm{a}$ & $7.7 \pm 0 \mathrm{ab}$ & $0.40 \pm 0.13 \mathrm{bc}$ \\
C15 & $273.3 \pm 22.4 \mathrm{bcd}$ & $108.3 \pm 12.5 \mathrm{~d}$ & $7.2 \pm 0.1 \mathrm{a}$ & $7.7 \pm 0 \mathrm{ab}$ & $0.40 \pm 0.08 \mathrm{bc}$ \\
S5 & $249.3 \pm 29.9 \mathrm{~cd}$ & $100.8 \pm 15.0 \mathrm{~d}$ & $7.2 \pm 0 \mathrm{a}$ & $7.6 \pm 0.1 \mathrm{~b}$ & $0.41 \pm 0.11 \mathrm{bc}$ \\
FC & $201.0 \pm 45.1 \mathrm{c}$ & $34.8 \pm 14.1 \mathrm{e}$ & $7.2 \pm 0 \mathrm{a}$ & $7.8 \pm 0.1 \mathrm{a}$ & $0.18 \pm 0.09 \mathrm{c}$ \\
\hline
\end{tabular}

${ }^{1} \mathrm{~N}$ drawdown index $(\mathrm{NDI})=\left[\mathrm{NO}_{3}\right.$ at day 4$] /\left[\mathrm{NO}_{3}\right.$ at day 0$]$, conducted with $300 \mathrm{mg} \mathrm{N} \mathrm{L}{ }^{-1}$. Different small letters indicate statistically significant differences in means among substrates at each column (Tukey's HSD, $p \leq 0.05$, mean \pm standard deviation, $\mathrm{n}=4)$. Miscanthus $\times$ giganteus was harvested with a forage harvester $(\mathrm{FC}$, field-chips), then processed with a mechanical fraying facility through a 5-mm screen (S5, shreds) or a hammermill with screen sizes of $15,10,5$, and $3 \mathrm{~mm}(\mathrm{C} 15, \mathrm{C} 10, \mathrm{C} 5$, and $\mathrm{C} 3$, chips).

\subsection{Growth of Chinese Cabbage Seedlings}

The final germination rate of Chinese cabbage (one week after sowing) was not affected by substrate treatment (Figure 8). However, seedling emergence was faster in peat and coir than in miscanthus substrates (at days 3, 4, 5, and 6). It could be that the seeds fell deeper in miscanthus substrate due to coarser substrate size, so it took longer for the cotyledons to appear above the substrate surface. No significant difference in germination rate was observed among any of the miscanthus substrates.

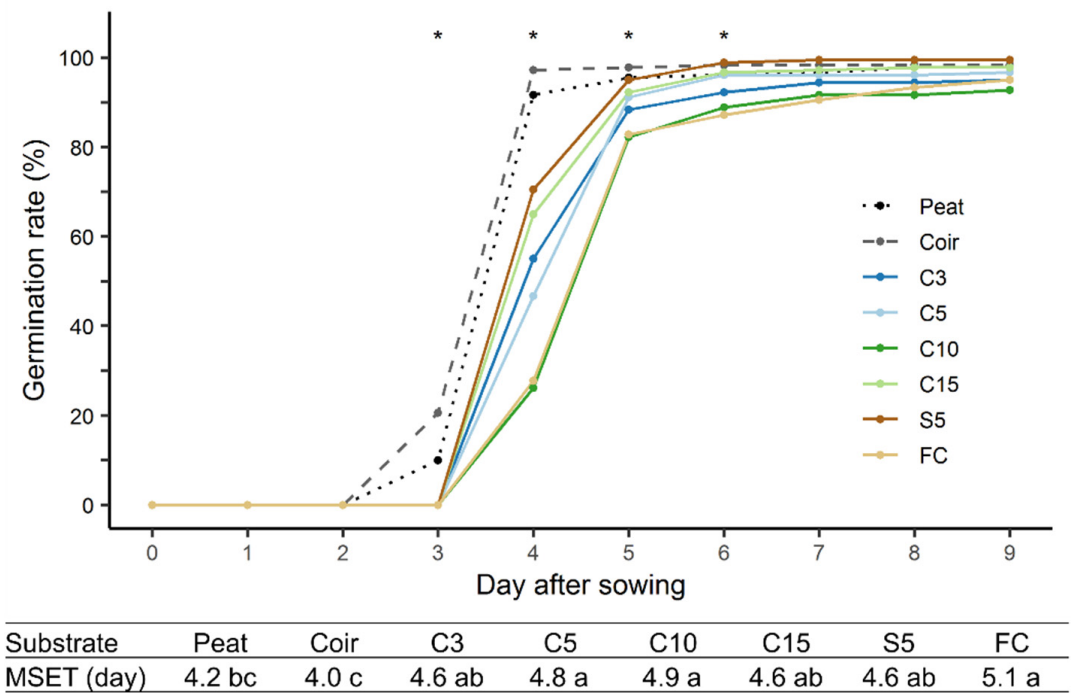

Figure 8. Germination rate of Chinese cabbage on peat, coir, and processed miscanthus substrates. Each point is the mean of germination rate of 4 trays. Each tray consists of 45 seeds. The asterisks at days $3,4,5$, and 6 represent for significant differences in germination rate among tested growing 
media and different letters indicate significant differences for MSET (Tukey's HSD, $p \leq 0.05$ ). Miscanthus $\times$ giganteus was harvested with a forage harvester (FC, field-chips), then processed with a mechanical fraying facility through a $5-\mathrm{mm}$ screen (S5, shreds) or a hammermill with screen sizes of $15,10,5$, and $3 \mathrm{~mm}(\mathrm{C} 15, \mathrm{C} 10, \mathrm{C} 5$, and C3, chips).

In the extract solution from the sowing cells, $\mathrm{pH}, \mathrm{EC}$, and water-soluble nutrient concentrations showed different results among peat, coir, and miscanthus substrates (Figure 9). While the $\mathrm{pH}$ of peat and coir remained at an approximate $\mathrm{pH}$ of 5.5 during the cultivation length of 24 days, the $\mathrm{pH}$ of miscanthus substrates increased quickly to 8.0 after 4 days and maintained higher $\mathrm{pH}$ values through day 24 . Among miscanthus substrates, toward the end of cultivation, the finer substrates $(\mathrm{C} 3, \mathrm{C} 5)$ tended to have higher $\mathrm{pH}$ and EC values than the coarser substrates (C10, C15, S5, and FC) (Supplementary Table S3). The $\mathrm{NO}_{3}$ and $\mathrm{Ca}$ concentration in extract solution of miscanthus treatments were lower than those of peat and coir substrates. Contrarily to low $\mathrm{NO}_{3}$ and Ca concentration, miscanthus substrates had a higher concentration of $\mathrm{NH}_{4}, \mathrm{~K}$, and $\mathrm{P}$ compared to peat and coir. No clear difference in those concentrations among miscanthus substrates was found. These high concentrations could result from the water soluble and easily released nutrients inherently present in the miscanthus feedstock (Table 2). A similar pattern was observed in the extract solution from sowing cells with seedlings (Supplementary Table S4).
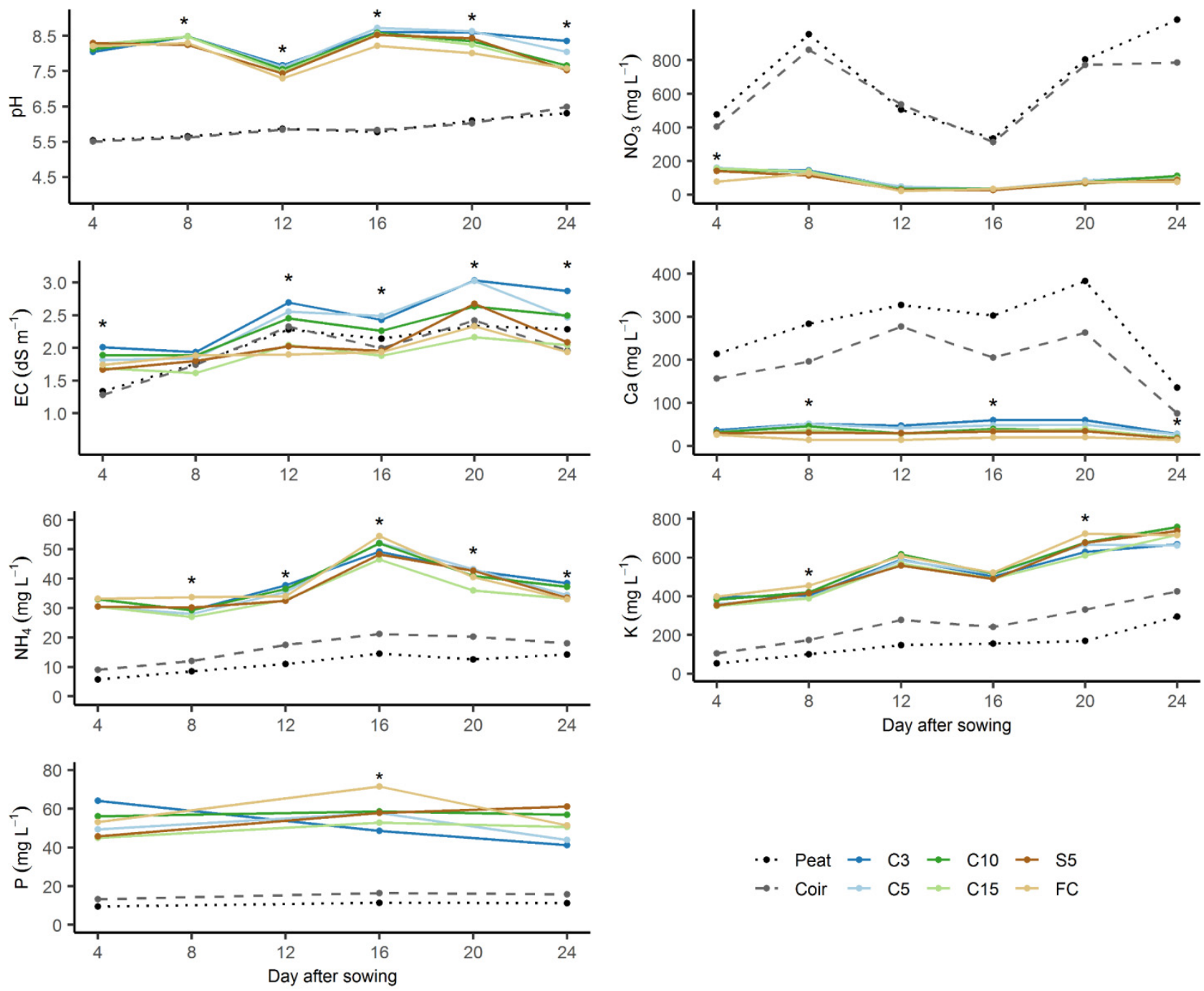

$$
\begin{aligned}
& \rightarrow \text { Peat } \rightarrow \mathrm{C} 3 \rightarrow \mathrm{C} 10 \rightarrow \mathrm{S} 5 \\
& \rightarrow \text { Coir } \rightarrow \mathrm{C} 5 \rightarrow \mathrm{C} 15 \rightarrow \mathrm{FC}
\end{aligned}
$$

Figure 9. The $\mathrm{pH}, \mathrm{EC}$ and water-soluble nutrients concentration in the extract substrate solution (saturation method). For each substrate, one data point represents for the mean of 4 replicates (each replicate consists of 3 sowing cells without having plants). Miscanthus $\times$ giganteus was harvested 
with a forage harvester (FC, field-chips), then processed with a mechanical fraying facility through a 5-mm screen (S5, shreds) or a hammermill with screen sizes of 15, 10, 5, and $3 \mathrm{~mm}$ (C15, C10, C5, and C3, chips). The asterisks represent for significant differences among tested growing media and different letters (A Tukey's HSD, $p \leq 0.05$ ), details are given in Table S3.

Seedlings on miscanthus substrates produced less fresh biomass ( 5 times), dry biomass (2 times), and smaller leaf area (3 times) than those on peat and coir (Figure 10). For leaf morphology, seedlings on miscanthus substrates showed smaller and thicker leaves (as leaf mass area) than those plants grown on peat or coir. Among miscanthus substrates, seedlings on FC produced the lowest biomass. Few differences on seedling growth were seen among the other miscanthus substrates, except the $\mathrm{C} 15$ which had a higher dry seedling biomass. The shapes of violin plots indicated the homogeneous distribution of seedling parameters in each substrate treatment. In general, seedlings on miscanthus substrates developed evenly compared to seedlings grown in peat or coir.
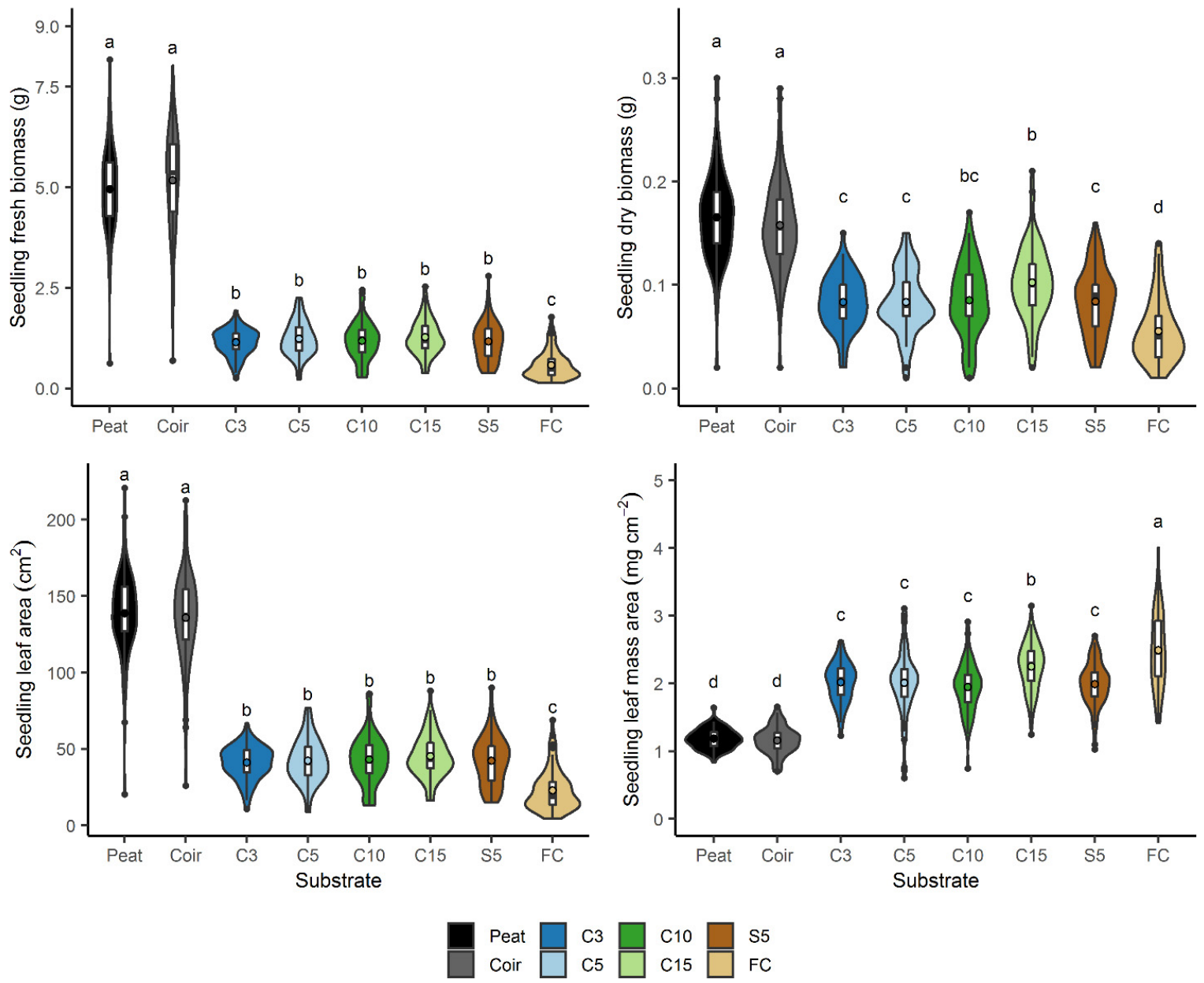

Figure 10. Seedling growth on peat, coir, and six processed miscanthus substrates: seedling fresh biomass, dry biomass, leaf area and leaf mass area. The violin plot represents the data distribution of 72 single seedlings at each substrate ( 4 replicates $\times 18$ seedlings). The boxplot inside represents median, interquartile ranges and mean value as point. The width of the violin represents the number of value in each range. Different small letters indicate statistically significant differences in means among substrates (Tukey's HSD, $p \leq 0.05$, mean \pm standard deviation, $\mathrm{n}=72$ ). Miscanthus $\times$ giganteus was harvested with a forage harvester (FC, field-chips), then processed with a mechanical fraying facility through a 5-mm screen (S5, shreds) or a hammermill with screen sizes of 15, 10, 5, and $3 \mathrm{~mm}$ (C15, C10, C5, and C3, chips). 
The leaf spectral reflectance showed a difference at the wavelength of approximately $550 \mathrm{~nm}$ indicating a difference in chlorophyll content (Figure 11). The ascending order of reflectance was (peat, coir) $<\mathrm{C} 15<(\mathrm{S} 5, \mathrm{C} 10, \mathrm{C} 5, \mathrm{C} 3)<\mathrm{FC}$. As an indicator for chlorophyll content, the vegetative indices Carter and Datt were negatively and positively correlated to leaf chlorophyll content, respectively [50]. From the leaf spectral reflectance, computed indices Carter and Datt showed that peat and coir had the highest chlorophyll content; C15 and other miscanthus substrates with FC had the lowest chlorophyll content.
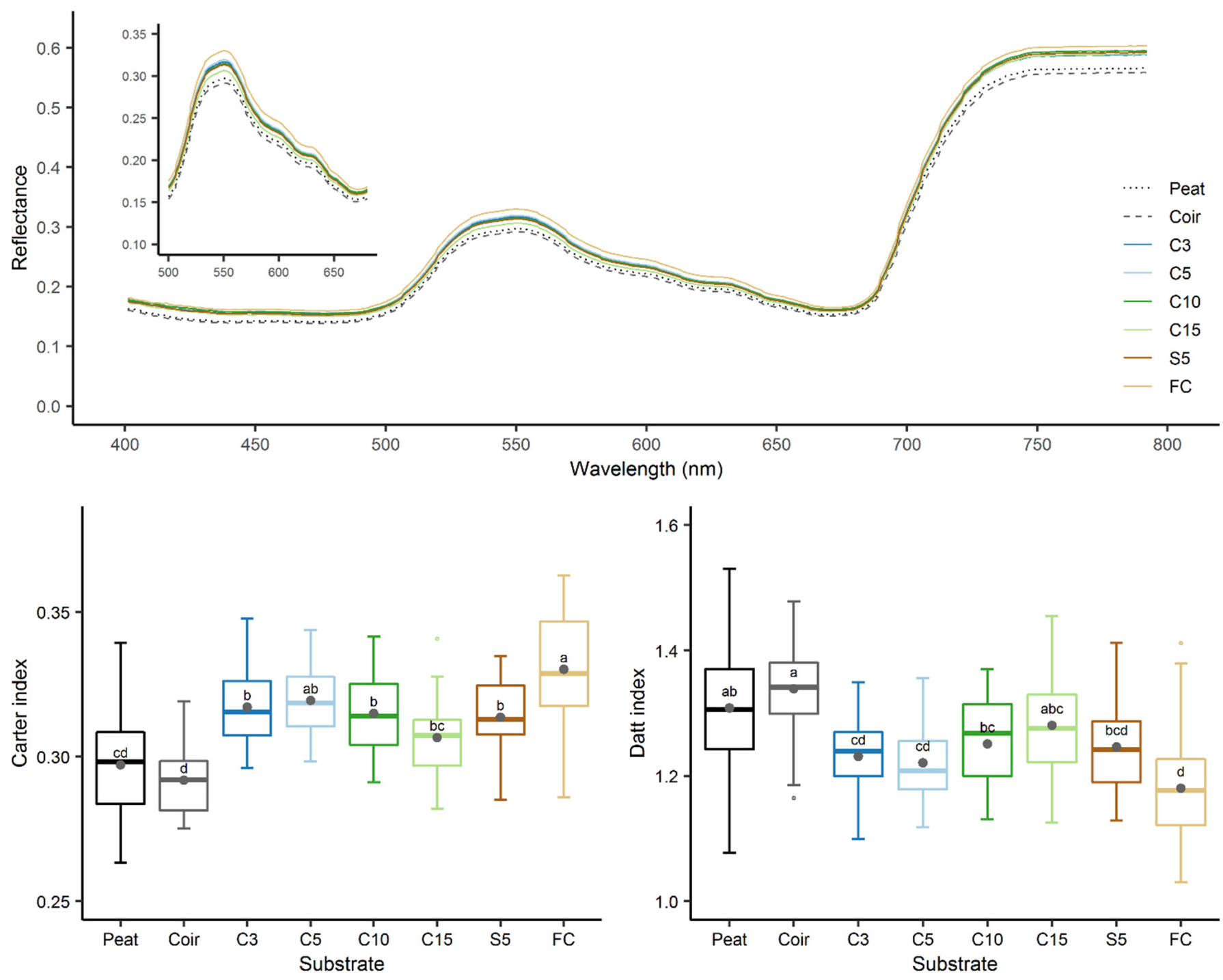

Figure 11. Spectral reflectance measured on the first leaf of Chinese cabbage seedlings at day 23 and computed vegetation index Carter6 and Datt4 based on reflectance at 550,672, and $708 \mathrm{~nm}$. Different small letters indicate statistically significant differences in means among substrates (Tukey's HSD, $p \leq 0.05, \mathrm{n}=24)$. Miscanthus $\times$ giganteus was harvested with a forage harvester (FC, field-chips), then processed with a mechanical fraying facility through a 5-mm screen (S5, shreds) or a hammermill with screen sizes of $15,10,5$, and $3 \mathrm{~mm}$ (C15, C10, C5, and C3, chips).

\section{Discussion}

\subsection{Effects of Substrate Morphology on Substrate Hydrological Properties}

Primary mechanical processing of miscanthus created different substrate morphology, which strongly influenced the physical properties of the substrates. First, regarding particle size, reducing particle size increased WHC in miscanthus and reduced air-filled porosity, following the same grouping pattern in particle size distribution (C3, C5, C10-C15-S5, FC). 
In the group of $\mathrm{C} 10, \mathrm{C} 15$, and S5, although reducing the screen size of the hammermill from $15 \mathrm{~mm}$ to $10 \mathrm{~mm}$ or processing with mechanical fraying facility, these substrates showed similar WHC values $(\sim 45 \%, v / v)$. On the other hand, the shifting screen size of hammermill from $10 \mathrm{~mm}$ to $5 \mathrm{~mm}$ and $5 \mathrm{~mm}$ to $3 \mathrm{~mm}$ showed a strong increase in WHC (from WHC of $45 \%$ to $54 \%$ and $62 \%$ in C10, C5, and C3, respectively) (Figure 4). In studies on coir, pine tree substrate, and pine bark, an increase in WHC mainly resulted from an increase in the proportion of fine particle $(<0.5 \mathrm{~mm})[24,28,29]$. Reducing screen size increased the time the miscanthus biomass / feedstock spent inside the hammermill, thus increasing the proportion of fine particles. We observed that the proportion of fine particles (in particle width) was similar among C10, C15, and S5, while it increased three times to five times when shifting screen size from $10 \mathrm{~mm}$ to $5 \mathrm{~mm}$ and $3 \mathrm{~mm}$, respectively (Table 4). Our data on particle size distribution (by volume) using digital image analysis also showed the same tendency to the data in weight based using traditional sieves described by Altland, 2010 [8] and Altland and Locke, 2011 [9] in which miscanthus processed with hammermill equipped with screens from $0.95 \mathrm{~cm}$ to $0.48 \mathrm{~cm}$ increased its fine particle proportion from $19.4 \%$ to $37 \%(w / w)$ and WHC increased $10 \%(v / v)$ in the substrates. Also, the C10, C15, and S5 produced in this study showed their WHC within the lower limit in the acceptance range of $45-50 \%(v / v)$ with having an amount of approximately $10 \%(v / v)$ of fine particles. It is in the same finding for pine tree substrate that an amount of $10-15 \%(w / w)$ of fine particles $(<0.5 \mathrm{~mm})$ is required to get WHC within the acceptance range [29].

Second, regarding particle shape, the elongated shape of miscanthus increased the AFP of the substrate. The C3 had a similar WHC to peat $(62 \%$ vs. $67 \%, v / v)$ but a higher AFP $(29 \%$ vs. $10 \%, v / v)$. This could be explained by the elongation of substrate particles. The C3 had more elongated particles than peat (Figure 3, Table 5). This influenced the arrangement of substrate particles, likely resulting in larger pore volumes between particles. Moreover, based on the soft and fibrous nature of the peatmoss, it was observed to be more easily blended in substrate formulations than C3 which had a different particle structure.

The substrate wettability of miscanthus showed a relationship with particle size and particle shape distribution. In general, miscanthus substrates showed a low and a reversible risk of hydrophobicity. Hydrophobicity of miscanthus could be explained by the natural waxes which are located mainly on the leaf cuticles and the outer stem [56]. The harvested miscanthus consisted of mainly stem biomass with inner porous hydrophilic parenchyma [57-59] and a small proportion of dried leaf tissue. Reducing particle size could reduce the barrier to water absorption into the hydrophilic parenchyma.

In miscanthus, with the reduction in particle size there was a reduction in hydrophobicity, except the S5 (Table 6). The shredded miscanthus showed a higher tendency of hydrophobicity (same group with the coarse FC) despite having the same grouping in particle size with C15 and C10 (with slightly smaller size) (Table 4). It meant the shredded material could have more of a barrier to water absorption into the inner parenchyma than the hammermilled substrates. According to particle shape analysis, S5 had a smoother surface than hammermilled substrates (Figure 3, Table 5) which could leave less of an open entrance through the hydrophobic cuticles into the hydrophilic inner area.

In the sowing trays, we observed no hydrophobic effect in miscanthus, except the coarse FC. The moisture in the first week showed no effect on the germination rate (Figure 8). At the end of the growing period, only the FC showed about $1 / 3-1 / 2$ top layer dry, and the other miscanthus moistened all the sowing cells (Supplementary Figure S4). The C3 and the $C 5$ were evenly wet, which could be due to a higher capillary rise potential and the less hydrophobic nature of the finer particles. At harvest, C10, C15, and S5 showed some particles had dried on the surface but it was not remarkable.

\subsection{Effects of Substrate Morphology on Substrate $p H$}

Substrate morphology showed no effect on the $\mathrm{pH}$ and the $\mathrm{pH}$ buffering capacity of fresh miscanthus substrates (Table 7). However, in sowing trays, the $\mathrm{pH}$ in the substrate solution of fine substrates (C3, C5) was higher than in coarser substrates (C10, C15, S5, 
and FC) (Supplementary Table S3). The $\mathrm{pH}$ in the substrate solutions of $\mathrm{C} 3$ and $\mathrm{C} 5$ were significantly higher than that of C10, C15, S5, and FC with the difference of 0.3-0.9 unit at day 24. Altland and Krause, 2009 [31] observed the same pattern for switchgrass substrate, where fine substrate (hammermilled with screen size of $0.48 \mathrm{~cm}$ ) had a higher $\mathrm{pH}$ than coarse substrate (hammermilled with screen size of 1.25 and $2.5 \mathrm{~cm}$ ).

According to the $\mathrm{pH}$ buffering test, miscanthus had a low buffering capacity, which was similar to the assumptions of Altland, 2010 [8] and Vandecasteele et al., 2018 [23]. However, in the sowing trays, the $\mathrm{pH}$ in miscanthus substrates shifted quickly from the input $\mathrm{pH}$ value of 5.5 to $\mathrm{pH} 7.5-8$ (Figure 9). Two assumptions for this $\mathrm{pH}$ increase are (1) miscanthus released $\mathrm{HCO}_{3}$ from its material, thus increasing the substrate $\mathrm{pH}$ as observed by Guo-jing et al., 2002 [14] in the drainage solution of mix miscanthus and wood fiber in tomato cultivation, and (2) microbe activity in miscanthus substrates released $-\mathrm{OH}$, causing a pH increase as assumed by Domeño et al., 2009 [60] in the drainage solution of wood fiber. Regarding the first assumption on $\mathrm{HCO}_{3}$ released from miscanthus feedstock, in a preliminary test on washing substrates, the $\mathrm{pH}$ of non-washed and washed substrates increased to a similar extent (Supplementary Figure S5). Also, in the NDI test, the $\mathrm{pH}$ in the extract solution in miscanthus also increased after 4 days of incubation. Therefore, we assumed that the increase in substrate $\mathrm{pH}$ could be from the increase in microorganism activity. Future study should focus on the interaction between microorganism activity (N immobilization) and the evolution of $\mathrm{pH}$ substrate.

\subsection{Effects of Substrate Morphology on N Immobilization}

Differences in $\mathrm{N}$ immobilization were seen in the coarse miscanthus materials. In general, the coarse FC immobilized about $80 \%$ of $\mathrm{N}$ applied (retained at day 0 ) which was similar to the findings for chopped miscanthus [23]. The finer miscanthus C3 and C5 showed similar N immobilization degree to the medium C10, C15, and S5 (approximately $60 \% \mathrm{~N}$ applied was immobilized) (Table 8).

In sowing trays, at a very early stage (day 4), the $\mathrm{NO}_{3}$ concentration in the extract solution in miscanthus was reduced (lower) relative to what was measured in peat and coir. This confirmed a strong $\mathrm{N}$ immobilization occurred in miscanthus, which could be at least partly explained by microbial activity and the particle surface area. Among miscanthus substrates, the finer tend to have a higher $\mathrm{NO}_{3}$ concentration, but without significant difference (Supplementary Table S3). This tendency could be due to the higher WHC of finer particles. The $\mathrm{NH}_{4}$ in miscanthus was higher than in peat and coir, and it remained stable during cultivation (Figure 9). Miscanthus substrates could release a high amount of $\mathrm{NH}_{4}$ from their biomasses, contributing to a higher $\mathrm{NH}_{4}$ as observed in the extracted solution (Table 3). As there was surplus $\mathrm{NO}_{3}$, the microbes could prefer to assimilate the $\mathrm{NO}_{3}$ than the $\mathrm{NH}_{4}$.

\subsection{Seedling Growth and Nutrients Available from Miscanthus Substrates}

The seedlings grown on miscanthus produced lower biomass and leaf area than those in peat and coir (Figure 10). The seedlings in miscanthus substrates did not show any visual $\mathrm{N}$-deficient symptom, such as leaf yellowing, but their leaves were smaller and thicker than those in peat and coir. This could be explained by the lower $\mathrm{NO}_{3}$ concentration and the lower Ca concentration in the substrate solution (Figure 9), as low Ca concentration could cause stunt growth and restricted leaf development [51]. We assumed that lower Ca concentration in the miscanthus substrate solution could result from (1) leaching, (2) binding Ca into the negatively charged sites on miscanthus substrates, and (3) precipitation formed between ion $\mathrm{Ca}^{2+}$ and $\mathrm{PO}_{4}{ }^{3-}$ in the miscanthus substrate solution. According to the preliminary test on cation exchange capacity, miscanthus had low exchange capacity for $\mathrm{Ca}$ (Supplementary Table S5). It suggested that just a small amount of Ca might be bounded onto the miscanthus surface. A lower Ca concentration in miscanthus substrates could be mainly from leaching effect and precipitation form. Moreover, the high concentration of 
$\mathrm{NH}_{4}, \mathrm{~K}$, and $\mathrm{P}$ could cause conditions unfavorable to seedling growth, especially under low $\mathrm{NO}_{3}$ concentration.

Dry biomass and vegetative indices data showed a tendency that $\mathrm{C} 15$ somehow performed better than the other miscanthus substrates (Figure 11). The C15 had a similar $\mathrm{NDI}$ and $\mathrm{NO}_{3}$ concentration in the substrate solution to other miscanthus substrates, except FC. Therefore, we assumed that a higher dry biomass of seedlings grown in C15 did not result from less $\mathrm{N}$ immobilization but possibly from a less unfavorable condition caused by less $\mathrm{NH}_{4}$ released from the substrate at very early cultivation (Tables 3 and S3) as seedlings are more sensitive to $\mathrm{NH}_{4}$. As the largest substrate after $\mathrm{FC}, \mathrm{C} 15$ might release slightly less $\mathrm{NH}_{4}$ than other finer substrates (Table 3). Although the difference in $\mathrm{NH}_{4}$ might not be noticeable in the substrate solution, it may enhance seedling growth in C15. Future study to improve miscanthus performance should focus not only on reducing $\mathrm{N}$ immobilization but also on increasing $\mathrm{Ca}$ and reducing $\mathrm{NH}_{4}, \mathrm{~K}$, and $\mathrm{P}$ concentration in miscanthus substrate.

\section{Conclusions}

Altering substrate morphology via mechanical processing strongly affects substrate hydrological properties and slightly affects substrate $\mathrm{pH}$ buffering capacity and $\mathrm{N}$ immobilization in miscanthus. Reducing particle size generally increases WHC and reduces AFP following grouping in proportion of fine particles $(<0.5 \mathrm{~mm})$. The risk of hydrophobicity decreases with reducing particle size in the interaction with roughness of particle surface. The substrate morphology showed no effect on $\mathrm{pH}$ and the $\mathrm{pH}$ buffering capacity of fresh substrate, but the finer substrates tend to have a higher $\mathrm{pH}$ than the coarse substrate in the cultivation. The amount of $\mathrm{N}$ immobilization was higher in coarse substrate but similar between medium and fine substrates. While further modifications are required to enhance nutrient availability in the substrate solution, this study shows that by selecting proper mechanical processing we could tailor substrate hydrological properties to certain crops' needs.

Supplementary Materials: The following supporting information can be downloaded at: https: / /www.mdpi.com/article/10.3390/agronomy12020420/s1, Figure S1. Visual appearance of peat, coir and six processed miscanthus substrates $(\mathrm{bar}=1 \mathrm{~cm})$. Miscanthus $\times$ giganteus was harvested with forage harvester (FC, field-chips), then processed with a mechanical fraying facility through a 5-mm screen (S5, shreds) or a hammermill with screen sizes of 15, 10, 5 and $3 \mathrm{~mm}$ (C15, C10, C5 and C3, chips). Figure S2. Substrate wettability: packing bulk density, initial moisture content of peat, coir and processed miscanthus substrates. Miscanthus $\times$ giganteus was harvested with forage harvester (FC, field-chips), then processed with a mechanical fraying facility through a 5-mm screen (S5, shreds) or a hammermill with screen sizes of 15, 10, 5 and $3 \mathrm{~mm}$ (C15, C10, C5 and C3, chips). Figure S3. Substrate $\mathrm{pH}$ buffering capacity: time to $\mathrm{pH}$ stabilization. The curves represent for mean values of S5 and C3. Different lower case letters indicate statistically significant differences in means among time points at each proton concentration (Tukey's HSD, $p \leq 0.05$, mean \pm standard deviation, $\mathrm{n}=10$ ). The time at $24 \mathrm{~h}$ after acid addition was selected as time when $\mathrm{pH}$ stabilization. At $48 \mathrm{~h}$ after acid addition, fungal mycelium on surface of substrate suspension was observed. Figure S4. Seedlings at harvest day, from left to right: peat, coir, FC, S5, C15, C10, C5, C3. Figure S5. pH evolution of washed and non-washed substrates. Table S1. Substrate porosity: wet mass and bulk density of substrates at packing, porosity mean of substrates. Table S2. Nutrient concentration of input nutrient solution for seedling growth. Table S3. $\mathrm{pH}, \mathrm{EC}$ and water-soluble nutrients from extract solution of sowing cells without plants. Table S4. $\mathrm{pH}$, EC and water-soluble nutrients from extract solution of cells with plants. Table S5. Cation exchange capacity (CEC) of miscanthus substrates $\mathrm{M} . \times$ giganteus $(\mathrm{n}=2)$ using ammonium acetate.

Author Contributions: Conceptualization, V.T.H.N., T.K. and R.P.; methodology, V.T.H.N. and T.K.; formal analysis, V.T.H.N. and T.K.; investigation, V.T.H.N., W.W. and S.A.; resources, R.P. and T.K.; data curation, V.T.H.N.; writing — original draft preparation, V.T.H.N.; writing—review and editing, V.T.H.N., B.E.J., R.P. and T.K.; visualization, V.T.H.N.; supervision, R.P., B.E.J. and T.K. All authors have read and agreed to the published version of the manuscript. 
Funding: This research was funded for an individual PhD grant for V.T.H.N. by Catholic Academic Exchange Service (KAAD).

Institutional Review Board Statement: Not applicable.

Informed Consent Statement: Not applicable.

Data Availability Statement: The data presented in this study are available on request from the corresponding author.

Acknowledgments: The authors would like to thank the whole team of Campus Klein-Altendorf for technical support, in particular Achim Kunz for assistance in conducting experiments, Georg Völkering and Julian Elfers as trial technicians for miscanthus cultivation and providing the feedstock, and Manuel Knauf for assistance in NDI test. Moreover, we specially thank the Bejo company for kindly donating seeds of Chinese cabbage free of charge.

Conflicts of Interest: The authors declare no conflict of interest.

\section{References}

1. Blok, C.; Eveleens, B.; van Winkel, A. Growing media for food and quality of life in the period 2020-2050. Acta Hortic. 2021, 1305, 341-356. [CrossRef]

2. Barrett, G.E.; Alexander, P.D.; Robinson, J.S.; Bragg, N.C. Achieving environmentally sustainable growing media for soilless plant cultivation systems-A review. Sci. Hortic. 2016, 212, 220-234. [CrossRef]

3. Gruda, N.S. Increasing Sustainability of Growing Media Constituents and Stand-Alone Substrates in Soilless Culture Systems. Agronomy 2019, 9, 298. [CrossRef]

4. Schmilewski, G. The View from Europe; HDC News Growing Media Report: England, UK, 2012; pp. 5-7.

5. Clifton-Brown, J.C.; Stampfl, P.F.; Jones, M.B. Miscanthus biomass production for energy in Europe and its potential contribution to decreasing fossil fuel carbon emissions. Glob. Chang. Biol. 2004, 10, 509-518. [CrossRef]

6. Heaton, E.A.; Dohleman, F.G.; Miguez, A.F.; Juvik, J.A.; Lozovaya, V.; Widholm, J.; Zabotina, O.A.; McIsaac, G.F.; David, M.B.; Voigt, T.B.; et al. Chapter 3-Miscanthus: A promising biomass crop. In Advances in Botanical Research; Kader, J.-C., Delseny, M., Eds.; Academic Press: Cambridge, MA, USA, 2010; pp. 75-137. ISBN 0065-2296.

7. Lewandowski, I.; Clifton-Brown, J.C.; Scurlock, J.M.O.; Huisman, W. Miscanthus: European experience with a novel energy crop. Biomass Bioenergy 2000, 19, 209-227. [CrossRef]

8. Altland, J. Use of Processed Biofuel Crops for Nursery Substrates. J. Environ. Hortic. 2010, 28, 129-134. [CrossRef]

9. Altland, J.E.; Locke, J.C. Use of Ground Miscanthus Straw in Container Nursery Substrates. J. Environ. Hortic. 2011, 29, 114-118. [CrossRef]

10. Babelewski, P.; Pancerz, M.; Dębicz, R.; Wacławowicz, R. Dynamics of C, N and C/N ratio in substrates based on miscanthus straw in container production of Spiraea japonica 'Macrophylla'. Acta Hortic. 2019, 1266, 129-136. [CrossRef]

11. Cárthaigh, D.; Sturm, A.; Schmugler, A. The Use of Miscanthus as A Growing Medium Additive. Acta Hortic. 1997, 450, 57-62. [CrossRef]

12. Frangi, P.; Amoroso, G.; Piatti, R. Alternative Growing Media to Peat Obtained from Two Fast Growing Species of Poaceae. Acta Hortic. 2012, 927, 967-972. [CrossRef]

13. Pancerz, M.; Babelewski, P. Influence of miscanthus-based growing media with the amendment of hydrogel and different multicomponent fertilizers on the fresh biomass of Hydrangea arborescens 'Annabelle'. Acta Hortic. 2019, 1266, 237-242. [CrossRef]

14. Li, G.J.; Benoit, F.; Ceustermans, N.; Xu, Z.H. The possibilities of Chinese reed fibres as an environmentally sound organic substrate. Acta Agric. 2002, 14, 87-94.

15. Babelewski, P.; Pancerz, M. Rooting of selected ornamental shrubs in substrates based on miscanthus straw. Acta Hortic. 2018, 1191, 175-182. [CrossRef]

16. Debode, J.; De Tender, C.; Cremelie, P.; Lee, A.S.; Kyndt, T.; Muylle, H.; De Swaef, T.; Vandecasteele, B. Trichoderma-Inoculated Miscanthus Straw Can Replace Peat in Strawberry Cultivation, with Beneficial Effects on Disease Control. Front. Plant Sci. $2018,9,213$. [CrossRef] [PubMed]

17. Vandecasteele, B.; Viaene, J.; Debode, J.; Muylle, H.; Perneel, M. Selecting raw materials for sustainable growing media: A protocol to assess the risk for N immobilization. Acta Hortic. 2017, 1168, 149-160. [CrossRef]

18. Kraska, T.; Kleinschmidt, B.; Weinand, J.; Pude, R. Cascading use of Miscanthus as growing substrate in soilless cultivation of vegetables (tomatoes, cucumbers) and subsequent direct combustion. Sci. Hortic. 2018, 235, 205-213. [CrossRef]

19. Nguyen, V.; Elfers, J.; Kühn, H.; Kraska, T.; Pude, R. Different Miscanthus genotypes as growing media in soilless tomato cultivation and its subsequent use for combustion. Acta Hortic. 2021, 1305, 301-308. [CrossRef]

20. Jensen, H.K.; Leth, M.; Iversen, J.L. Growth of Hedera helix and Fatsia japonica Pot Plants in Compost Substrates Based on Miscanthus Straw and Various N-Sources. Acta Hortic. 2001, 549, 137-146. [CrossRef]

21. Jensen, H.E.K.; Leth, M.; Iversen, J.J.L. Growth of Hedera helix L. Container Plants in Compost Substrates Made with Miscanthus ogiformis Honda Straw and Various N-Sources. Compos. Sci. Util. 2001, 9, 206-214. [CrossRef] 
22. Jensen, H.E.K.; Leth, M.; Iversen, J.J.L. Effect of Compost Age and Concentration of Pig Slurry on Plant Growth. Compos. Sci. Util. 2002, 10, 129-141. [CrossRef]

23. Vandecasteele, B.; Muylle, H.; De Windt, I.; Van Acker, J.; Ameloot, N.; Moreaux, K.; Coucke, P.; Debode, J. Plant fibers for renewable growing media: Potential of defibration, acidification or inoculation with biocontrol fungi to reduce the $\mathrm{N}$ drawdown and plant pathogens. J. Clean. Prod. 2018, 203, 1143-1154. [CrossRef]

24. Abad, M.; Fornes, F.; Carrión, C.; Noguera, V.; Noguera, P.; Maquieira, A.; Puchades, R. Physical Properties of Various Coconut Coir Dusts Compared to Peat. HortScience 2005, 40, 2138-2144. [CrossRef]

25. Cannavo, P.; Michel, J.-C. Peat particle size effects on spatial root distribution, and changes on hydraulic and aeration properties. Sci. Hortic. 2013, 151, 11-21. [CrossRef]

26. Caron, J.; Rivière, L.-M.; Guillemain, G. Gas diffusion and air-filled porosity: Effect of some oversize fragments in growing media. Can. J. Soil Sci. 2005, 85, 57-65. [CrossRef]

27. Gruda, N.; Sippel, C.; Schnitzler, W. Investigation of Physical Properties of Wood Fiber Substrates under Press Pot Conditions Acta Hortic. 2001, 51-58. [CrossRef]

28. Handreck, K. Particle size and the physical properties of growing media for containers. Commun. Soil Sci. Plant Anal. 1983, 14, 209-222. [CrossRef]

29. Jackson, B.E.; Wright, R.D.; Barnes, M.C. Methods of Constructing a Pine Tree Substrate from Various Wood Particle Sizes, Organic Amendments, and Sand for Desired Physical Properties and Plant Growth. HortScience 2010, 45, 103-112. [CrossRef]

30. Jackson, B.E.; Wright, R.D. Pine Tree Substrate: An Alternative and Renewable Substrate for Horticultural Crop Production. Acta Hortic. 2009, 819, 265-272. [CrossRef]

31. Altland, J.E.; Krause, C. Use of Switchgrass as a Nursery Container Substrate. HortScience 2009, 44, 1861-1865. [CrossRef]

32. Jackson, B.E.; Wright, R.D.; Barnes, M.C. Pine Tree Substrate, Nitrogen Rate, Particle Size, and Peat Amendment Affect Poinsettia Growth and Substrate Physical Properties. HortScience 2008, 43, 2155-2161. [CrossRef]

33. Owen, W.G.; Jackson, B.E.; Whipker, B.E.; Fonteno, W.C. Pine Wood Chips as an Alternative to Perlite in Greenhouse Substrates: Nitrogen Requirements. HortTechnology 2016, 26, 199-205. [CrossRef]

34. Wallach, R. Physical Characteristics of Soilless Media. In Soilless Culture: Theory and Practice, 2nd ed.; Raviv, M., Lieth, H., Bar-Tal, A., Eds.; AP Academic Press: London, UK, 2019; pp. 33-112. ISBN 9780444636966.

35. DIN EN 13037:2012-01; Soil Improvers and Growing Media-Determination of pH, German version EN 13037:2011; German version EN 13037:2011; Beuth Verlag: Berlin, Germany, 2012. [CrossRef]

36. DIN EN 13038:2012-01; Soil Improvers and Growing Media-Determination of pH, German version EN 13038:2011; German version EN 13038:2011; Beuth Verlag: Berlin, Germany, 2011. [CrossRef]

37. DIN EN 13652:2002-01; Soil improvers and Growing Media-Extraction of Water Soluble Nutrients and Elements, German version EN 13652:2001; German version EN 13652:2001; Beut Verlag: Berlin, Germany, 2002. [CrossRef]

38. Retsch Technology GmbH. CAMSIZER Characteristics -Basis of Definition DIN 66141; Retsch Technology GmbH: Haan, Germany, 2009.

39. Drzal, M.; Cassel, D.K.; Fonteno, W. Pore Fraction Analysis: A New Tool for Substrate Testing. Acta Hortic. 1999, 481, 43-54. [CrossRef]

40. Microtrac Retsch GmbH. Determination of Particle Shape with Dynamic Image Analysis. Available online: https://www microtrac.com/dltmp/www/5e396c09-23f8-45ca-ae33-7f30c3c9c754-cce0895c57d1/tr_particle_shape_1118_en.pdf (accessed on 11 May 2021)

41. Malvern Instruments Ltd. A Basic Guide to Particle Characterization. 2015. Available online: https://www.malvernpanalytical com/en/learn/knowledge-center/whitepapers/WP120620BasicGuidePartChar (accessed on 12 September 2021).

42. Miller, N.A.; Henderson, J.J. Quantifying Sand Particle Shape Complexity using a Dynamic, Digital Imaging Technique. Agron. J. 2010, 102, 1407-1414. [CrossRef]

43. Miller, N.A.; Henderson, J.J. Correlating Particle Shape Parameters to Bulk Properties and Load Stress at Two Water Contents. Agron. J. 2011, 103, 1514-1523. [CrossRef]

44. Microtrac Retsch $\mathrm{GmbH}$. Whitepaper: Correlation between Sieve Analysis and Image Analysis Made Easy, n.d. Available online: https: / / www.microtrac.com/products/particle-size-shape-analysis/dynamic-image-analysis/camsizer-p4/downloads / dl_details/1/file/5e396c09-86c8-42f5-a041-7f30c3c9c754/ (accessed on 10 May 2021).

45. Fonteno, W.C.; Harden, C.T. Procedures for Determining Physical Properties of Horticultural Substrates Using the NCSU Porometer; Horticultural Substrates Laboratory, North Carolina State University: Raleigh, NC, USA, 2003.

46. Fonteno, W.; Fields, J.; Jackson, B. A Pragmatic Approach to Wettability and Hydration of Horticultural Substrates. Acta Hortic. 2013, 1013, 139-146. [CrossRef]

47. Fields, J.S.; Fonteno, W.C.; Jackson, B.E. Hydration Efficiency of Traditional and Alternative Greenhouse Substrate Components. HortScience 2014, 49, 336-342. [CrossRef]

48. Costello, R.C.; Sullivan, D.M. Determining the pH Buffering Capacity of Compost Via Titration with Dilute Sulfuric Acid. Waste Biomass-Valoriz. 2014, 5, 505-513. [CrossRef]

49. Handreck, K.A. Rapid assessment of the rate of nitrogen immobilisation in organic components of potting media: I. Method development. Commun. Soil Sci. Plant Anal. 1992, 23, 201-215. [CrossRef]

50. Main, R.; Cho, M.A.; Mathieu, R.; O'Kennedy, M.M.; Ramoelo, A.; Koch, S. An investigation into robust spectral indices for leaf chlorophyll estimation. ISPRS J. Photogramm. Remote Sens. 2011, 66, 751-761. [CrossRef] 
51. Bunt, A.C. Media and Mixes for Container-Grown Plants: A Manual on the Preparation and Use of Growing Media for Pot Plants, Second Edition of Modern Potting Composts; Springer: Dordrecht, The Netherlands, 1988; ISBN 9401179042.

52. Johnson, E. Comparison of methods of analysis for loamless composts. Acta Hortic. 1980, 197-204. [CrossRef]

53. Yeager, T.; Fare, D.; Lea-Cox, J.; Ruter, J.; Bilderback, T.E.; Gilliam, C.; Niemiera, A.; Warren, S.L.; Whitwell, T.; Wright, R.D.; et al. Best Management Practices: Guide for Producing Container-Grown Plants, 2nd ed.; Southern Nurserymen's Assoc: Marietta, GA, USA, 1997.

54. Michel, J.-C.; Jackson, B.; Fonteno, W. Classification of organic substrates' wettability from contact angle measurements and hydration efficiency tests. Acta Hortic. 2017, 1168, 199-206. [CrossRef]

55. Benoit, F.; Ceustermans, N. Consequences of closed soilless growing systems for the recirculating nutrient solution and the production techniques. Acta Hortic. 2004, 633, 331-340. [CrossRef]

56. Attard, T.M.; McElroy, C.R.; Gammons, R.J.; Slattery, J.M.; Supanchaiyamat, N.; Kamei, C.L.A.; Dolstra, O.; Trindade, L.M.; Bruce, N.C.; McQueen-Mason, S.J.; et al. Supercritical $\mathrm{CO}_{2}$ Extraction as an Effective Pretreatment Step for Wax Extraction in a Miscanthus Biorefinery. ACS Sustain. Chem. Eng. 2016, 4, 5979-5988. [CrossRef]

57. Botto, L.; Preuss, K.; Robertson, L.X.; Xu, X.Y. Physical characterisation and yield stress of a concentrated Miscanthus suspension. Rheol. Acta 2014, 53, 805-815. [CrossRef]

58. Klímek, P.; Wimmer, R.; Meinlschmidt, P.; Kúdela, J. Utilizing Miscanthus stalks as raw material for particleboards. Ind. Crop Prod. 2018, 111, 270-276. [CrossRef] 
59. Pude, R. Morphological, Chemical and Technical Parameters of Miscanthus Genotypes. J. Appl. Bot. Food Qual. $2004,78,58-63$.

60. Domeño, I.; Irigoyen, I.; Muro, J. Evolution of organic matter and drainages in wood fibre and coconut fibre substrates. Sci. Hortic. 2009, 122, 269-274. [CrossRef] 